\title{
Alberta Piping Plover Recovery Plan 2010-2020
}
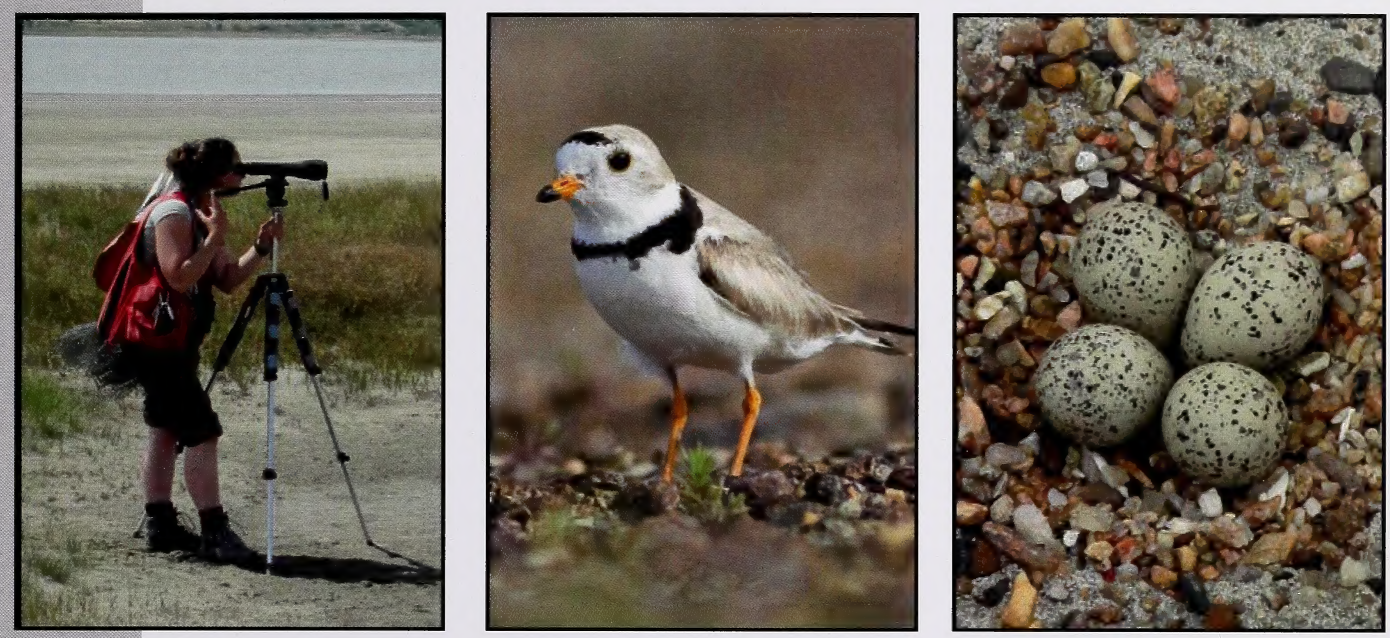

Alberta Species at Risk Recovery Plan No. 18

Government of Alberta 
Digitized by the Internet Archive in 2016 


\section{Alberta Piping Plover Recovery Plan 2010-2020}

Prepared by:

The Alberta Piping Plover Recovery Team

David R. C. Prescott (Team Leader) - Alberta Sustainable Resource Development (Fish and Wildlife Division)

Michael Barr - Ducks Unlimited Canada/North American

Waterfowl Management Plan

Lance C. Engley - Alberta Conservation Association

J. Paul Goossen - Canadian Wildlife Service

Gerald A. Haekel - Alberta Sustainable Resource Development (Lands Division)

D. Edward Hofman - Alberta Sustainable Resource Development (Fish and Wildlife

Division)

Dug Major - Special Areas Board

Dave Moore - Alberta Sustainable Resource Development (Fish and Wildlife Division) Juanna Thompson - Nature Conservancy of Canada

\section{March 2010}

\section{Government of Alberta}


Publication No.: $\mathrm{I} / 424$

ISBN: 978-0-7785-8907-5 (Printed Edition)

ISBN: 978-0-7785-8908-2 (On-line Edition)

ISSN: $1702-4897$ (Printed Edition)

ISSN: 1702-4900 (On-line Edition)

Cover photos: left: L. Engley; center and right: D. Prescott

For copies of this report, contact:

Information Centre - Publications

Alberta Sustainable Resource Development

Main Floor, Great West Life Building

9920 - 108 Street

Edmonton, Alberta, Canada T5K 2M4

Telephone: (780) 422-2079

\section{OR}

Visit the Species at Risk Program web site at:

http://srd.alberta.ca/BioDiversityStewardship/SpeciesAtRisk/Default.aspx

This publication may be cited as:

Alberta Piping Plover Recovery Team. 2010. Alberta Piping Plover Recovery Plan, 20102020. Alberta Sustainable Resource Development, Fish and Wildlife Division, Alberta Species at Risk Recovery Plan No. 18. Edmonton, AB. 28 pp. 


\section{PREFACE}

Albertans are fortunate to share their province with a diverse variety of wild species. Populations of most species of plants and animals are healthy and secure. However, a small number of species are either naturally rare or are now imperilled because of human activities. Recovery plans establish a basis for cooperation among government, industry, conservation groups, landowners and other stakeholders to ensure these species and populations are restored or maintained for future generations.

Alberta's commitment to the Accord for the Protection of Species at Risk and to the National Framework for the Conservation of Species at Risk, combined with requirements established under Alberta's Wildlife Act and the federal Species at Risk Act, has resulted in the development of a provincial recovery program. The overall goal of the recovery program is to restore species identified as Threatened or Endangered to viable, naturally self-sustaining populations within Alberta. The policy document: Alberta's Strategy for the Management of Species at Risk (2009-2014) provides broader program context for recovery activities.

Alberta species at risk recovery plans are prepared under the supervision of the Fish and Wildlife Division, Alberta Sustainable Resource Development. These recovery plans are prepared by recovery teams composed of a variety of stakeholders including conservation organizations, industry, landowners, resource users, universities, government agencies and others. Membership is by invitation from the Director of Wildlife Management, and includes representation from the diversity of interests unique to each species and circumstance. Conservation and management of these species continues during preparation of the recovery plan.

The Director of Wildlife Management provides these plans as advice to the Minister responsible for fish and wildlife management. Alberta's Endangered Species Conservation Committee also reviews draft recovery plans, and provides recommendations to the Minister. Additional opportunities for review by the public may also be provided. Plans accepted and approved for implementation by the Minister are published as a government recovery plan. Approved plans are a summary of the Department's commitment to work with involved stakeholders to coordinate and implement conservation actions necessary to restore or maintain these species.

Recovery plans include three main sections: background information that highlights the species' biology, population trends, and threats; a recovery section that outlines goals, objectives, and strategies to address the threats; and an action plan that profiles priority actions required to maintain or restore the Threatened or Endangered species. These plans are "living" documents and are revised as conditions change or circumstances warrant. Each approved recovery plan undergoes an annual review, and progress of implementation is evaluated. Implementation of each recovery plan is subject to the availability of resources, from within and from outside government. 


\section{TABLE OF CONTENTS}

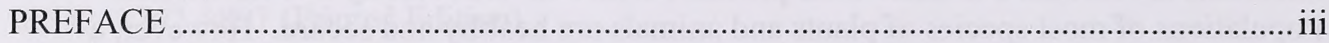

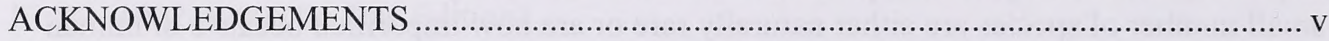

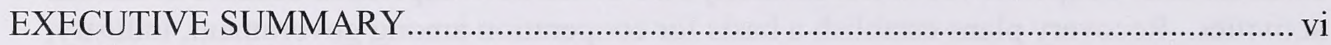

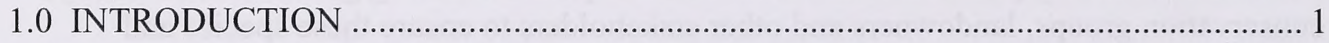

1.1 Provincial and Federal Status .................................................................. 1

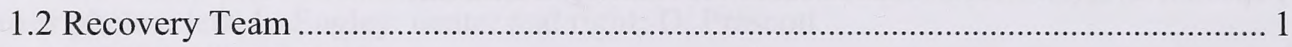

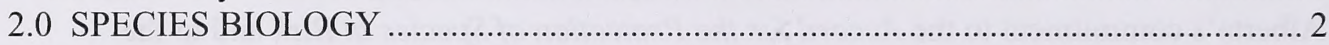

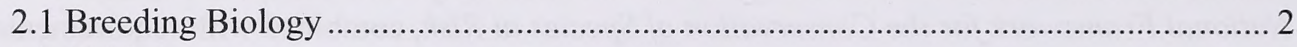

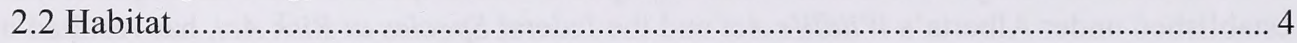

2.3 Population Size, Distribution and Trends in Alberta ............................................ 4

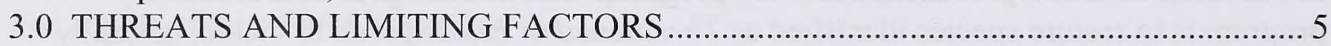

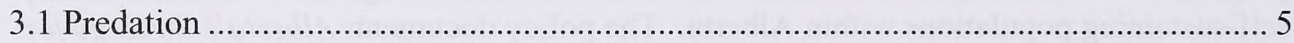

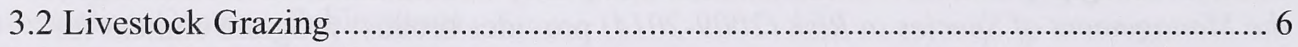

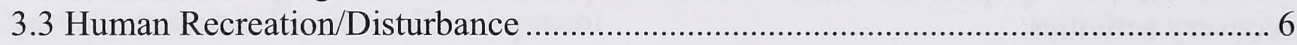

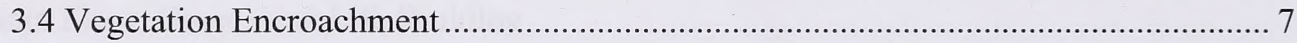

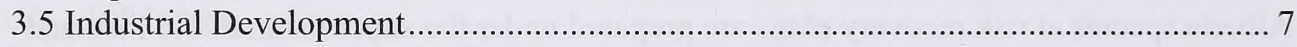

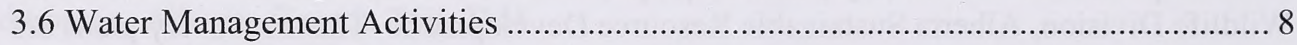

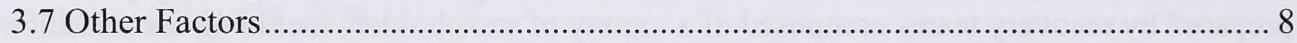

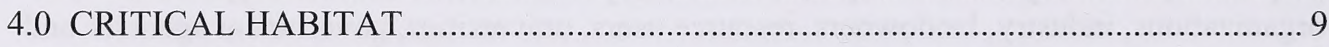

5.0 RESEARCH NEEDS ............................................................................... 10

6.0 RECENT RECOVERY AND CONSERVATION EFFORTS ............................... 10

7.0 RECOVERY STRATEGY ........................................................................ 11

7.1 Biological and Technical Feasibility of Recovery ........................................ 11

7.2 Guiding Principles...................................................................................... 12

7.3 Recovery Goal........................................................................................ 13

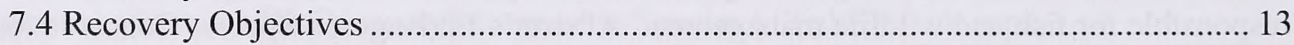

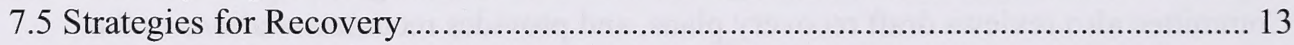

8.0 ACTION PLAN ..................................................................................... 14

8.1 Habitat Management and Protection................................................................. 14

8.2 Productivity Enhancement ....................................................................... 15

8.3 Information and Outreach ........................................................................ 15

8.4 Population Monitoring and Research.......................................................... 15

8.5 Plan Management and Administration.................................................... 16

8.6 Resource Acquisition .................................................................................... 16

9.0 IMPLEMENTATION SCHEDULE AND COSTS ............................................ 16

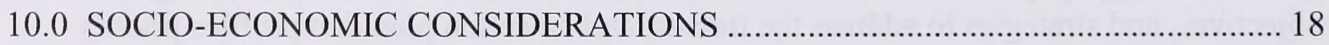

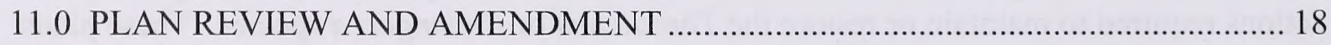

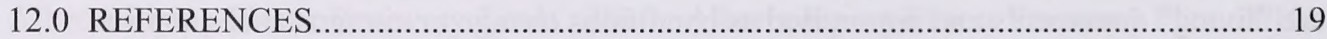

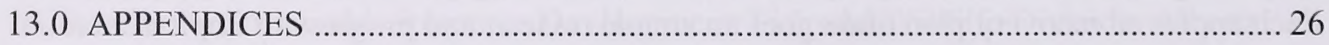




\section{ACKNOWLEDGEMENTS}

The members of the Alberta Piping Plover Recovery Team thank their respective organizations for providing in-kind support for the preparation of this plan. Dan Sturgess, Roy Schmelzeisen and Amanda Rezansoff (Alberta Conservation Association) were instrumental in the implementation and success of the Alberta Piping Plover Recovery Plan 2005-2010, and provided valuable input into development of the new plan. We also thank Craig Horner (Alberta Beef Producers) for past contributions to the Alberta Piping Plover Recovery Team. Scott Stevens and Cindy Kemper provided editorial comments on an earlier draft.

Funding from the Species at Risk Program of Alberta Sustainable Resource Development, and in-kind support from the Alberta Conservation Association, supported the preparation of the Alberta Piping Plover Recovery Plan, 2010-2020. 


\section{EXECUTIVE SUMMARY}

The piping plover (Charadrius melodus) is a small shorebird that breeds on sand or gravel beaches on the Atlantic coast, Great Lakes and Great Plains. Birds spend the winter along the southeastern Atlantic seaboard and the coast of the Gulf of Mexico, including some Caribbean islands. Approximately 8000 individuals occur within the North American range, with approximately $30 \%$ of these breeding in Canada. The species' range and population size has declined in recent decades, and the piping plover is listed as an Endangered or Threatened species throughout its North American range. In Canada, the species is considered to be Endangered under the federal Species at Risk Act (SARA). Reasons for the population decline include increasing levels of predation, and disturbance or habitat deterioration due to agricultural, industrial and recreational use of shorelines.

In Alberta, piping plovers have been reported from at least 86 lakes in the southern half of the province, with breeding confirmed on 52 lakes. The provincial distribution varies annually, and is determined by local water conditions. In any given year, the species occurs on 20-25 lakes in the province, with the majority of the population occurring on 3-6 lakes. Since provincial surveys began in 1987, the provincial population has ranged from 134 to 294 individuals, with latter number being observed in 2008 .

In February 2000, the piping plover was listed as Endangered in Alberta, because of a low population size $(<250)$, threats to habitat, and an inability of existing management to increase population levels. Shortly thereafter, the Minister of Sustainable Resource Development initiated recovery actions with the issuance of an Initial Conservation Action Statement, and the establishment of a multi-stakeholder recovery team that would advise the Minister on all matters relating to piping plover conservation in the province. This team produced the Alberta Piping Plover Recovery Plan, 2002-2004, which aimed to recover piping plover populations in Alberta through the protection of nests and the conservation of habitat through cooperative initiatives with land users. This plan was followed by the Alberta Piping Plover Recovery Plan, 2005-2010. Successful completion of both plans resulted in a reduction in human impacts on plover habitat, and yielded breeding productivity that met or exceeded the stated target of 1.25 chicks/pair/year in most years. The Alberta Piping Plover Recovery Plan, 2010-2020 represents a continuation of efforts to recover and conserve piping plovers in Alberta. The specific guiding principles, goals, objectives, strategies and management actions remain largely unchanged from the most recent plan (2005-2010).

This recovery plan is guided by the following principles: (1) the recovery of piping plovers in Alberta is both achievable and desirable; (2) a loss of habitat and individuals is unacceptable; (3) a cooperative approach with landowners, industry and other agencies is essential; (4) management actions will employ tools resulting in the most immediate benefit to piping plovers and will be based on the best information available; (5) landowners and leaseholders will not be unduly affected by the costs associated with recovery measures; (6) activities will be restricted to a small number of effective and achievable actions; (7) recovery actions will embrace an ecosystem (holistic) approach to management; (8) predator management activities will be accomplished through passive 
means; and (9) the recovery process will be guided by the concept of adaptive management.

The recovery goal for Alberta is to achieve a well-distributed, long-term average population of 300 individual piping plovers within their historical range in the province. During implementation of the Alberta Piping Plover Recovery Plan, 2010-2020, the objectives continue to be as follows:

(1) To minimize anthropogenic impacts on the quantity and quality of piping plover habitat;

(2) To employ all management techniques possible to achieve a median fledging rate of greater than 1.25 chicks/pair/year in the province;

(3) To increase public awareness of piping plovers and their management in Alberta; and

(4) To monitor the progress of past and current management efforts in the province.

The goal and objectives of the recovery plan will be achieved by the implementation of six distinct strategies (habitat management and protection, productivity enhancement, information and outreach, population monitoring and research, plan management and administration, and resource acquisition), which will be pursued concurrently over the 10year period. A series of specific actions in each of these strategic areas is detailed, along with anticipated costs.

Management will occur in all areas of the province where plovers occur, but will be especially focused on areas designated under the federal Species at Risk Act as being "critical habitat" for the recovery of this endangered species. In Alberta, critical habitat areas include the crown-owned shorelines of 43 quarter sections of land on 13 lakes (Akasu, Baxter, Birch, Chain Lake “\#4”, Dowling, Handhills, Killarney, Little Fish, Muriel, "Piper", Red Deer, Sunken and "West" Reflex). These areas were selected as critical habitat based on their frequency and magnitude of use by piping plovers over the past 15 years, and on their importance in achieving the provincial recovery goal.

The overall cost of the actions detailed in the recovery plan is $\$ 2,020,000$ over 10 years, including both cash and essential "in-kind" support. A variety of agencies will be invited to participate in the funding and implementation of recovery initiatives. 


\subsection{INTRODUCTION}

\section{$\underline{1.1 \text { Provincial and Federal Status }}$}

In February 2000, the Minister of Sustainable Resource Development approved the up-listing of the piping plover (Charadrius melodus) from Threatened to Endangered in Schedule 6 of the Wildlife Regulation under Alberta's Wildlife Act, based on the recommendation from the Endangered Species Conservation Committee (ESCC). The status revision was based on Alberta's very small population $(<250)$, persistent threats to habitat, and an inability of recent management actions to increase population levels. The Minister's Initial Conservation Action Statement specified that a recovery plan would be prepared within 24 months, that those organizations with a stake in piping plover issues should be invited to participate in recovery planning, and that sufficient new resources should be made available to support essential conservation actions. Furthermore, the action statement advised that government land-use management systems should be strengthened on crown land to prevent the loss of nests, and that management should ensure the protection of nests (and associated habitats) through direct contact with landowner/disposition holders to facilitate voluntary conservation and/or the negotiation of cooperative management strategies.

In 2002, the Alberta Piping Plover Recovery Plan, 2002-2004 (Alberta Piping Plover Recovery Team 2002) was developed to embrace the directives of the Initial Conservation Action Statement. Following successful completion of the inaugural recovery plan, an updated plan, the Alberta Piping Plover Recovery Plan, 2005-2010 (Alberta Piping Plover Recovery Team 2006) was drafted and approved by the Minister of Sustainable Resource Development in April 2006. Implementation of recovery actions outlined in these plans has helped to reduce human impacts on plover habitat and has allowed productivity goals outlined in the plan to be met or exceeded (Alberta Piping Plover Recovery Team 2005, Prescott et al. 2010). The current plan, which will guide recovery efforts through 2020, represents a continuation and refinement of recovery and conservation efforts for piping plovers in Alberta.

Nationally, the piping plover was listed as Endangered in 2001 due to a small number of breeding pairs in Canada, decreasing population sizes and habitat quality, and low reproductive success (COSEWIC 2009). The species is now listed under the federal Species at Risk Act (SARA). In 2002, the National Recovery Plan for the Piping Plover was published (Goossen et al. 2002) and the Recovery Strategy for the Piping Plover (Charadrius melodus circumcinctus) in Canada was approved in 2006 (Environment Canada 2006). The Alberta Piping Plover Recovery Plan, 2010-2020 is intended to be compliant with SARA and to be compatible with recovery and conservation initiatives outlined in the federal recovery strategy for the circumcinctus subspecies.

\section{$\underline{1.2 \text { Recovery Team }}$}

The Alberta Piping Plover Recovery Team was initiated by the Minister of Sustainable Resource Development, and receives operational guidance and approval from the Director of Wildlife Management. The team's primary responsibility is to facilitate the conservation and recovery of piping plovers in Alberta, and to provide expert advice to the Minister on the management of this 
endangered species. The team is also responsible for writing the initial recovery plan, assisting with plan updates where necessary, and providing input to the Prairie Piping Plover Recovery Team on the management of piping plovers in Alberta. The team does not implement recovery actions directly, although team members and their associated organizations will participate in the recovery initiatives. Because of the multi-stakeholder nature of recovery issues, team membership will remain dynamic and strive for the best representation of affected parties. The team will encourage and facilitate the involvement of all interested parties in the recovery of piping plovers in Alberta, whenever possible, and will report annually on the progress of the recovery program.

\subsection{SPECIES BIOLOGY}

\section{$\underline{2.1 \text { Breeding Biology }}$}

The piping plover is a small, thrush-sized shorebird characterized by its pale colouration, high pitched 'piping' call, and habit of breeding on open sand or gravel beaches (Goossen et al. 2002, Elliott-Smith and Haig 2004). Three distinct breeding populations are recognized: the Atlantic coast (C. m. melodus), Great Lakes, and Great Plains (C. m. circumcinctus) populations. Birds breeding on the Atlantic coast tend to winter in coastal areas of the southeastern United States (Virginia to Florida), whereas the two inland-breeding populations generally winter from Florida to northern Mexico (Elliott-Smith and Haig 2004). Band returns indicate that most Alberta birds winter near the Texas/Mexico border, with individuals occurring as far east as the Atlantic coast of Florida and Georgia (Prescott et al. 2010). The continental population is approximately 8000 individuals, with about $30 \%$ of these breeding in Canada (Haig et al. 2005, Haig and Plissner 1993, Elliott-Smith et al. 2009). The population size and range of piping plovers have contracted in North America over the past few decades. The species has disappeared as a breeding bird from Illinois, Indiana, Ohio, Pennsylvania and New Hampshire, and populations have dropped to extremely low levels in Ontario, Manitoba and Iowa (Goossen et al. 2002, Elliott-Smith and Haig 2004).

In Alberta, piping plovers arrive on their breeding grounds in late April (Pinel et al. 1991, Heckbert 1994, Heckbert and Cantelon 1996). Males establish a territory and attract a mate with a combination of aerial and ground displays. Clutches usually contain four eggs (Whyte 1985, Elliott-Smith and Haig 2004). The latest clutch initiation for Alberta is recorded as 6 to 10 July (Alberta Fish and Wildlife Division 1991), but few nests are initiated after mid-June (Prescott et al. 2010). Incubation of eggs is shared by both sexes and lasts 26 to 28 days (Elliott-Smith and Haig 2004). Young leave the nest within several hours of hatching (Elliott-Smith and Haig 2004), and are capable of sustained flight between 18 and 25 days of age (Cairns 1982, Whyte 1985, Prindiville Gaines and Ryan 1988, Murphy et al. 1999). Most birds leave the Canadian prairies for the wintering grounds by the first week in August (Elliott-Smith and Haig 2004).

Reproductive success of piping plovers is highly variable among lakes and across years (Goossen 1994, Harris et al. 2005, Prescott et al. 2010). Females are capable of breeding at one year of age and will re-nest if the eggs are destroyed early in the season, but have only been known to produce one brood per year (Haig and Oring 1988a, Bottitta et al. 1997). Estimates of 
fledging success in Alberta calculated between 1994 and 2009 range from 0.12 to 2.02 young/pair (Figure 1). Increased fledging success in recent years is largely due to efforts to reduce predation on nests (predator exclosures) and to habitat stewardship by landholders and other stakeholders (Alberta Piping Plover Recovery Team 2005, Prescott et al. 2010). Various models have estimated that minimum productivity levels of between 1.13-1.7 young/pair are required to maintain stable populations on the Great Plains (Ryan et al. 1993, Plissner and Haig 2000). The most recent model suggests a median productivity of 1.25 chicks/pair/year is required (Larson et al. 2000). This value has been achieved in Alberta only four times since 1994, but was nearly achieved in at least six other years (Figure 1). Productivity values calculated for Alberta during the latest recovery effort (2005-2010) are calculated to be 1.19 chicks/pair/year (Prescott et al. 2010). However, these estimates are considered to be very conservative (Schmelzeisen et al. 2005), and the target production was probably exceeded in most years since intensive management began in 2002 .

Estimates of fidelity to breeding areas on the Great Plains range between $42 \%$ and $71 \%$ for adults, but are typically less than 14\% for juveniles (Whyte 1985, Haig and Oring 1988a,b, Root et al. 1992). Haig and Oring (1988b) demonstrated that fidelity is highest in areas with large amounts of suitable breeding habitat. Birds have been known to disperse up to $1500 \mathrm{~km}$ from one breeding season to the next (Haig and Oring 1988b). Approximately $90 \%$ of re-encounters with Alberta-banded birds during the breeding season occur within this province in subsequent years (Prescott et al. 2010), with the remainder being reported from lakes in Saskatchewan. This indicates that management initiatives and funds directed at the Alberta plover population directly benefit local birds.

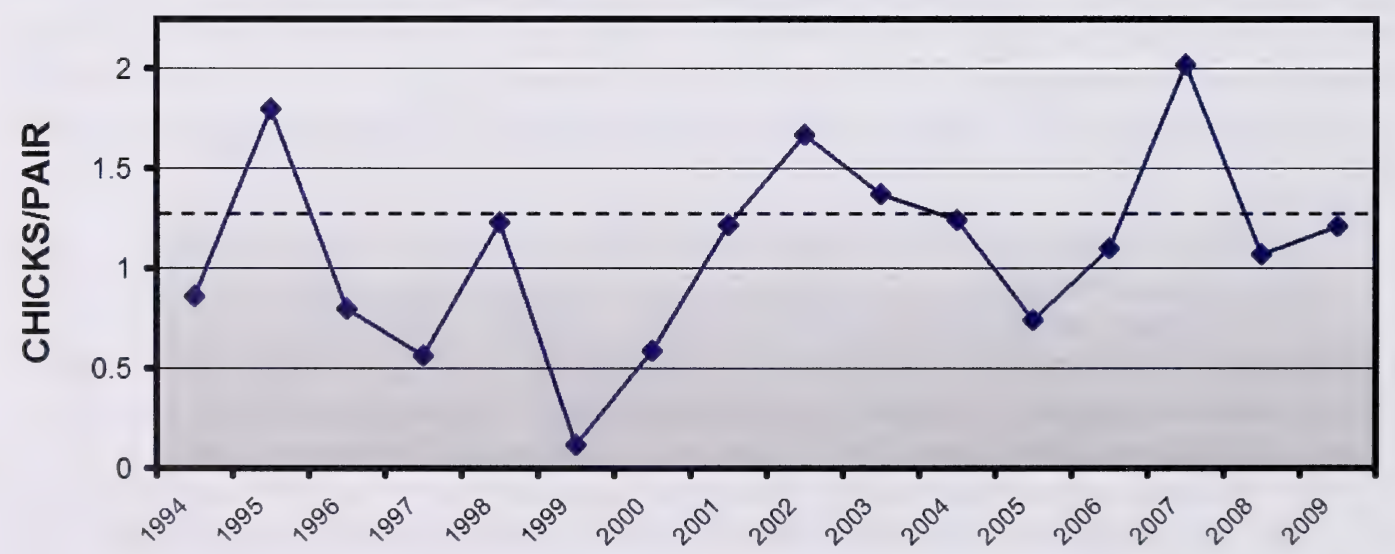

YEAR

Figure 1. Piping plover productivity (\# chicks/breeding pair) in Alberta, 1994-2009. The dashed line shows the production target of 1.25 chicks/pair required to maintain population size on the Great Plains population (Larson et al. 2000). 


\subsection{Habitat}

In Alberta, the piping plover generally inhabits shorelines and islands of large alkaline lakes (Prescott 1997). Nesting typically occurs on gravel substrates in areas with relatively wide, sparsely vegetated beaches. The availability of suitable nesting substrates for piping plovers depends on variations in water level on nesting lakes. Periodic high-water events may restrict beach width and temporarily limit the availability of nesting habitat, but eventual recession of water levels exposes gravel deposits which provide unvegetated breeding habitat for several years thereafter. Such variations in water levels are typical in prairie ecosystems. Habitat availability for plovers, and the presence and size of local breeding populations, can therefore differ greatly between years (Prescott 2001a).

\subsection{Population Size, Distribution and Trends in Alberta}

Piping plovers have been extensively surveyed in Alberta since the mid 1980s. The major surveys occur at five-year intervals (beginning in 1991) as part of the International Piping Plover Census which occurs on both the summer and winter ranges across North America (see Haig and Plissner 1993 for general survey information, and Hofman 1994, Bjorge 1997, Prescott 2001b and Prescott 2009 for Alberta-specific results). In addition, a major survey was conducted in 1986 (Wershler and Wallis 1987), and annual surveys that cover most of the provincial population have occurred annually since 2002 (Engley and Schmelzeisen 2002, Schmelzeisen and Engley 2003, Engley et al. 2004, Schmelzeisen et al. 2005, van Huystee et al. 2007, Rezansoff et al. 2006, 2008, 2009). Incidental observations contributed by consultants, biologists with non-government agencies, and the general public have also added to our knowledge of piping plover population size and distribution in the province.

Provincial population counts are summarized in Figure 2. Populations have ranged as high as 294 individuals in 2008, and as low as 134 birds in 2004. The number of lakes surveyed during each of the years has been highly variable, and dependent on local habitat conditions.

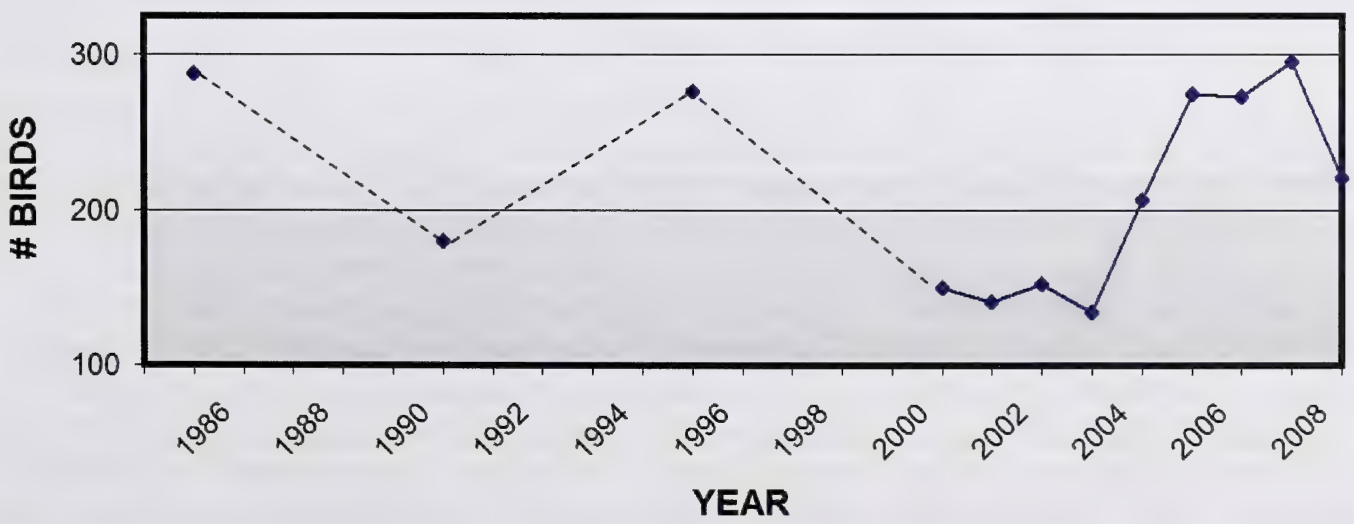

Figure 2. Piping plover population size in Alberta based on 12 provincial inventories conducted since 1986. 
Regardless of the number of lakes surveyed, piping plovers generally occur on 20-25 lakes each year, with $50 \%$ of the birds occurring on less than six lakes (Prescott et al. 2010). Of lakes surveyed a minimum of 10 years, only five (Chain “\#4", Dowling, Handhills, Muriel and "West" Reflex) have been known to support birds during every survey. Several other lakes (e.g. Akasu, Baxter, Birch and Killarney) contain extensive habitat, and generally support significant populations except during extreme drought conditions (Appendix 1).

To date, piping plovers have occurred on at least 86 lakes in the province (Appendix 1 and 2, Prescott et al. 2010). Although new waterbodies with plovers are occasionally found, it is believed that most basins capable of supporting substantial or consistent populations of plovers have been identified. To date, breeding has been confirmed on 52 of these lakes (Appendix 1).

Alberta populations in 2008 reached a level (294 individuals) similar to numbers counted during the first provincial survey in 1986 (Wershler and Wallis 1987), and the population on the Canadian prairies has increased by $19 \%$ since the first International Census is 1991 (Haig et al. 2005, Goossen et al. in prep.). However, the recent population size is still below levels established in previous recovery plans (Alberta Piping Plover Recovery Team 2002, 2006; Environment Canada 2006) and has followed almost a decade of intensive management.

\subsection{THREATS AND LIMITING FACTORS}

Limiting factors are considered to be those conditions that degrade habitat suitability, reduce survivorship of young or adults, or decrease nesting success of adults once they are established at a site (Prescott 1997). From a management standpoint, an understanding of these factors is important because they identify mechanisms through which plover recovery may be achieved. The limiting factors discussed below have been identified as affecting populations of piping plovers in Alberta (Wershler 1992, Prescott 1997, Goossen et al. 2002, Westworth et al. 2004, Alberta Piping Plover Recovery Team 2002, 2006, Environment Canada 2006). Management actions that have been used to mitigate some of these factors are also listed. However, not all actions may be applicable or practical for piping plover recovery in Alberta.

\section{$\underline{3.1 \text { Predation }}$}

Predation on eggs and chicks is the greatest source of reproductive failure in piping plovers on the Great Plains. Richardson (1999) found that $64 \%$ of nesting attempts in Alberta failed because of depredation. Recent analysis suggests that since 1994, the probability that an unprotected plover nest in Alberta will hatch is only 29\% (Engley and Prescott 2004, Prescott and Engley, unpubl. data). This value is apparently lower than anywhere else in North America. Instances of predation are rarely observed, and the types of predators are poorly documented (Haig et al. 1988). American crows (Heckbert 1994) and gulls (Heckbert and Cantelon 1996) are most often implicated in Alberta. However, black-billed magpies, common grackles, blackbirds, American ravens, great horned owls, northern harriers, merlins, ground squirrels, striped skunks, mink, red fox, coyotes, raccoons, weasels, white-tailed deer and domestic dogs have also been 
observed, or suspected of, preying upon eggs or young in central North America (Whyte 1985, Espie et al. 1992, Murphy et al. 2003, Ivan and Murphy 2005).

Although the loss of eggs and chicks to predators is a natural process, there is evidence that urbanization and recreational use of beaches have increased populations of gulls, foxes and skunks in some areas (Haig 1985). Little is known about adult mortality. However, mink, red fox, peregrine falcons, red-tailed hawks, great horned owls and merlins are known to be responsible for adult predation (Elliott-Smith and Haig 2004, Michaud and Prescott 1999, Murphy et al. 2003). Management tools available to decrease predation of nests and/or adults include predator removal, destruction of stick nests during the nonbreeding season, erection of electric fencing and the use of predator exclosures around nests (Melvin et al. 1992,

Schmelzeisen et al. 2004). A predator exclosure project initiated in Alberta in 1996 showed that fledging success rates of exclosed nests were more than double those of unprotected nests (Richardson 1999). More recent efforts to reduce predation on nests have been highly successful as well (Alberta Piping Plover Recovery Team 2005, Prescott et al. 2010).

\section{$\underline{3.2 \text { Livestock Grazing }}$}

Livestock can disturb nesting substrates, interfere with normal nesting behaviour by established birds, and directly destroy eggs. In addition, young plovers may fall into deep hoof prints and be unable to escape (Wershler and Wallis 1987, Hofman 1992). Furthermore, the construction of dugouts adjacent to shorelines can foul nesting beaches, change basin hydrology, and accelerate vegetative encroachment (Heckbert 1994). Studies have shown nesting success to be lower on territories with evidence of cattle activity (Prindiville Gaines and Ryan 1988, Hofman 1992). It should be noted, however, that grazing reduces vegetation on shorelines. Fall grazing has recently been used to slow the rate of vegetation encroachment and thereby improve habitat quality on Little Fish Lake in southern Alberta (Alberta Piping Plover Recovery Team 2005, Prescott et al. 2010).

During the 2001 International Piping Plover Census, grazing was assessed to be a potential threat on $66.3 \%$ of all lakes surveyed and on $69.6 \%$ of lakes containing plovers in Alberta (Prescott $2001 \mathrm{~b})$. These numbers are relatively consistent with those reported in $1991(66.7 \%$; recalculated from Hofman 1994) and 1996 (82.6\%; Bjorge and Murphy 2004). Despite the potentially negative effects of livestock on plover populations, impacts can be reduced by effective and inexpensive measures such as fencing, establishment of new water sources, and deferred grazing practices. Increased stakeholder awareness and habitat stewardship conducted since 2002 have greatly reduced the threat of grazing on piping plovers in Alberta (Alberta Piping Plover Recovery Team 2005, Prescott et al. 2010).

\subsection{Human Recreation/Disturbance}

Motorized off-road travel (all-terrain vehicles), or non-motorized, recreational use of beaches can affect plovers by directly destroying nests and eggs, or by interfering with feeding, territory establishment, and other reproductive behaviours (Cairns 1982, Flemming et al. 1988, Haig et al. 1988, Burger 1994). During the 2001 International Piping Plover Census, motorized vehicles were a threat on $18.6 \%$ of all lakes surveyed in Alberta, and on $34.8 \%$ of lakes supporting piping 
plovers. Similarly, recreational/residential use was determined to have an impact on $12.8 \%$ of lakes surveyed and $26.1 \%$ of lakes supporting plovers (Prescott 2001b). Since the late 1990s, the two lakes with the greatest populations of piping plover in Alberta also have cottage developments ("West" Reflex and Muriel lakes). Management activities aimed at reducing human disturbance typically include the erection of cautionary and interpretive signage, and contact with recreation and user groups to increase awareness of plovers and their conservation requirements. However, restrictions on shoreline use are occasionally necessary, such as at Muriel Lake where a seasonal wildlife sanctuary was created in 2003 to prevent disturbance to plovers (Alberta Piping Plover Recovery Team 2005).

\section{$\underline{3.4 \text { Vegetation Encroachment }}$}

The creation of suitable nesting habitat for piping plovers requires alternating periods of high and low water to remove vegetation and expose gravel substrates on nesting beaches (Prescott 1997). As water recedes, vegetation slowly invades the substrates until habitat becomes unsuitable for nesting, unless the beach is rejuvenated by high-water events. Although such encroachment is a natural occurrence, anthropogenic influences (i.e., grazing and water management) can affect the rate and extent of plant growth. Of particular concern is the stabilization of water bodies to improve recreational opportunities for humans. Such projects greatly diminish the probability of high-water events, and thereby reduce long-term habitat suitability for plovers. One example of this in Alberta is at Buffalo Lake, where stabilization in the 1990s has reduced habitat quality at the adjacent "Rider" Lake and Rockeling Bay, which supported significant plover populations in the 1980s and early 1990s (Goossen et al. 2000). Stabilization projects have been also proposed for other plover lakes in Alberta (e.g., Little Fish Lake [Goossen 1994]).

Management tools used to minimize vegetation encroachment include burning, herbicide use, mechanical ground disturbance and fall/winter grazing. Burning was attempted at Rockeling Bay in the mid-1990s with limited success. Mechanical clearing of vegetation has been recently employed at Red Deer Lake, and fall grazing is currently being used to manage habitat at Little Fish Lake (Alberta Piping Plover Recovery Team 2005, Prescott et al. 2010). These techniques have modestly improved habitat for plovers, but cannot fully reverse the normal progression of vegetation encroachment on shorelines.

\section{$\underline{3.5 \text { Industrial Development }}$}

Industrial activities (primarily oil and gas exploration and extraction) around plover breeding sites could pollute water and shorelines, deplete water levels or interfere with ground water dynamics, and eliminate surrounding vegetation (Wershler 1992). The direct impacts of oil and gas development on plover habitat are not well documented, but activity occurs in close proximity to numerous breeding sites in Alberta. During the 2001 International Piping Plover Census, industrial activity, including petroleum exploration/extraction, was assessed to be a potential threat on $10.5 \%$ of all lakes surveyed and on $13.0 \%$ of lakes supporting plovers in Alberta (Prescott 2001b). Higher oil and gas prices have led to even greater exploration and extraction in recent years, so the potential for impact from these industries is likely much higher than calculated in 2001 . 
The primary means of reducing the effects of industrial development include the placement of protective notations (PNTs) on public lands to alert developers to the presence of an endangered species, and the application of timing and setback restrictions (Alberta Sustainable Resource Development 2009) that minimize disturbance to breeding birds and their habitat. To date, PNTs, or similar notations in the Special Areas Management System (SAMS), have been placed on the beds and shores of 32 plover-inhabited lakes in Alberta (Prescott et al. 2010). In addition, the referral system has proven successful in obtaining support from industrial operators to limit impacts of development on plover habitat (Alberta Piping Plover Recovery Team 2005, Prescott et al. 2010).

\subsection{Water Management Activities}

Projects that stabilize water levels to enhance recreational opportunities can remove the natural fluctuation of water levels required to provide plover nesting habitat (see above). However, water levels on most large water impoundments are not static, and seasonal changes in water levels create suitable nesting substrates for piping plovers. Typically, water rises in the spring as snow melts, and then falls throughout the summer as irrigation and hydroelectric demands are met. If suitable habitat is exposed when plovers are establishing territories (early May), subsequent rising water can destroy nests and reduce or eliminate habitat necessary for brood rearing (Espie et al. 1992, Jung et al. 1998, Wiltermuth et al. 2009). In Alberta, water level fluctuations due to irrigation practices are known to have affected plovers breeding on Keho Lake (Wershler 1992). Fortunately, the use of reservoirs by piping plovers is quite low in this province (Prescott 2001b), but high nest losses often occur on reservoirs in Saskatchewan and in the United States (Espie et al. 1998, Goossen et al. 2002). In 2001, water management activities were identified as potential threats on $8.1 \%$ of Alberta lakes surveyed for the International Piping Plover Census and on $8.7 \%$ of lakes supporting plovers (Prescott 2001b).

\section{$\underline{3.7 \text { Other Factors }}$}

A variety of other factors can affect piping plover populations. Many of these factors, however, are either unpredictable or impossible to control or mitigate. For example, severe storms may cause nest losses and reduce fledging success (Murphy et al. 1995, Michaud and Prescott 1999). In addition, piping plovers spend only $30 \%$ of their annual cycle on the breeding grounds, so most adult bird mortalities likely occur in wintering areas or during migration (Root et al. 1992, U.S. Fish and Wildlife Service 2009). Events occurring outside of Alberta therefore have the potential for major impacts on local piping plover populations.

The cumulative impact of several independent limiting factors may pose an additional threat to piping plover populations. Thus, even when the independent negative effect of any one factor is assumed to be small, it may still pose a significant threat to the population in combination with other factors. In reference to the Alberta population, Prescott (2004) suggests "There is probably sufficient structural habitat to maintain the population, but the quality of this habitat is slowly deteriorating due to increasing predators and a variety of anthropogenic disturbances".

Finally, it must be stressed that piping plovers are habitat specialists, and that suitable breeding habitat occurs in a limited number of locations in the province. As a result, plovers occur on 
only 20-25 lakes in a given year, with the majority of these occurring on only 3-6 lakes where habitat conditions are optimal (Prescott et al. 2010). This highly concentrated distribution makes piping plovers particularly vulnerable to threats, and localized disturbances could have large consequences for the Alberta population.

\subsection{CRITICAL HABITAT}

Critical habitat is defined in the federal Species at Risk Act as "the habitat that is necessary for the survival or recovery of a listed wildlife species". The Alberta Piping Plover Recovery Team recognizes that all habitat for plovers in Alberta is worthy of management and protection. However, the team also recognizes that a subset of sites in the province is particularly important for protection, due to the frequency and magnitude of use by plovers, and its contribution towards the achievement of provincial management objectives. Criteria for the identification of critical habitat were detailed in the Alberta Piping Plover Recovery Plan 2005-2010 (Alberta Piping Plover Recovery Team 2006) and are based on the frequency and magnitude of occupancy by plovers as follows:

1) A floating window of 15 years (starting in 1991) to determine site status;

2) A minimum of five years of survey data within the 15 -year window;

3) Average number of plovers over all surveys on a lake being $\geq 4$ adults.

Specific areas of candidate lakes were selected as follows:

1) Use of shoreline by $\geq 2$ pairs of birds ( $\geq 4$ adults or $\geq 2$ nests) in $\geq 2$ breeding seasons over a 15-year window; or

2) Any documented use (probable or confirmed breeding) in $\geq 4$ seasons during the 15 -year period.

Based on these criteria, 43 quarter sections of shoreline on 13 lakes (Akasu, Baxter, Birch, Chain Lake “\#4", Dowling, Handhills, Killarney, Little Fish, Muriel, "Piper", Red Deer, Sunken and "West" Reflex) in Alberta were identified as critical habitat.

These areas were identified in the Alberta Piping Plover Recovery Plan, 2005-2010 in anticipation of eventual inclusion in the Recovery Strategy for the Piping Plover (Charadrius melodus circumcinctus) in Canada (Environment Canada 2006). Although the listing of critical habitat areas was initially omitted from the federal strategy, they were subsequently included in an addendum (Environment Canada 2007). With the national process for listing now in place, any updates and revisions to critical habitat in Alberta (and elsewhere) will defer to national processes. Given that the population distribution of plovers has remained relatively static in recent years, the current list of critical habitat areas in Alberta should remain relatively unchanged.

The critical habitat segments that are now listed for Alberta have been the focus of intensive and varied management over the past five years. This management includes cooperative agreements with adjacent landowners to protect and enhance breeding habitat, application of protective 
notations, erection of interpretive and cautionary signage, establishment of seasonal sanctuaries, and other measures. A complete listing of management activities on critical habitat in Alberta is provided by Prescott et al. (2010).

\subsection{RESEARCH NEEDS}

The biology and ecology of piping plovers are relatively well understood. Nevertheless, there are a number of knowledge gaps relating to plovers on the Canadian prairies that may be addressed through additional research. These include investigations into the dispersal, migration, and demographics of birds, a better understanding of the role of various threats (e.g. predation, grazing, water management) and landscape features (habitat availability, food abundance) in determining productivity, and the calculation and accuracy of fledging rate estimates (Environment Canada 2006). Research efforts contributing to the recovery and conservation of piping plovers in Alberta should focus on continuation of population and habitat monitoring to prioritize management approaches and assess whether recovery goals are being met. Research will also be directed towards identifying predators of piping plover nests, so that the design and deployment of nest exclosures and other productivity enhancement tools can be improved. Many activities undertaken during implementation of this plan will include some measure of data collection, analysis and interpretation, in order to consistently improve existing management techniques.

\subsection{RECENT RECOVERY AND CONSERVATION EFFORTS}

The Alberta Piping Plover Recovery Plan, 2002-2004, and the Alberta Piping Plover Recovery Plan, 2005-2010 outlined recovery strategies and actions necessary for the recovery and conservation of piping plovers in Alberta. All recovery actions outlined in these plans were implemented (see Alberta Piping Plover Recovery Team 2005, Prescott et al. 2010). Key initiatives included:

- Review and documentation of historical habitat use by piping plovers in the province on a lake and quarter-section basis

- Application to the Lands Division of Alberta Sustainable Resource Development and the Special Areas Management System for protective notations on 173 quarter sections of crown land on 32 lakes where plovers are known to have occurred

- Involvement in numerous referrals concerning industrial development around plover breeding lakes

- Completion of management plans for plovers on 30 lakes in the province

- Personal, and ongoing contact with most landowners, leaseholders and cottage owners adjacent to important habitat on at least 26 plover-inhabited lakes

- Completion of over 25 habitat-improvement projects on 12 lakes

- Establishment of a seasonal sanctuary to prevent disturbance of plovers on Muriel Lake

- Widespread use of predator exclosures to greatly increase the hatching success of plover nests 
- Completion of a review of predator management techniques applicable to plovers in Alberta

- Designation of 43 quarter sections of land on 13 lakes as "critical habitat" for piping plovers under the federal Species at Risk Act

- Numerous presentations to technical and non-technical audiences on plovers and their management

- Periodic surveys of cottag owners on Muriel Lake that show continuing high support for plover management and access restrictions on the lake

- Preparation and distribution of an information package, and preparation and circulation of an annual newsletter to landowners

- Completion of breeding pair and brood surveys on between 25 and 44 lakes each year, including discovery of new populations on at least six Alberta lakes

- Banding of 879 chicks since 1994, and compilation of 686 re-encounters with birds on the breeding grounds and on wintering areas along the Gulf of Mexico

- Compilation of plover productivity data gathered since 1994

- Securement of $\$ 1,231,000$ in cash funding and at least $\$ 462,000$ of in-kind support from numerous individuals and agencies.

Most importantly, these activities resulted in two of the three recovery goals outlined in the plan being met or exceeded. Specifically, these activities protected plover habitat quality and quantity from impacts of human activities, and resulted in fledging success rates that exceeded 1.25 chicks/pair/year in each year between 2002-2004, and averaged 1.19 chicks/pair/year between 2005 and 2010. However, the main goal of the recovery program - the attainment of a welldistributed, long-term average population of 300 individual piping plovers within their Alberta range - has yet to be achieved. This goal is seen as a long-term target of the recovery program, and will require continued work to be realized, and ongoing management to be maintained (Alberta Piping Plover Recovery Team 2005, Prescott et al. 2010).

\subsection{RECOVERY STRATEGY}

\subsection{Biological and Technical Feasibility of Recovery}

Under the federal Species at Risk Act, a species is considered to be recoverable if all of the following criteria apply (Environment Canada 2009a): (1) individuals capable of reproduction are available; (2) sufficient habitat is present to support the population, or such habitat could be made available through management or restoration; (3) threats to the species can be alleviated or mitigated; and (4) the necessary recovery techniques exist and are demonstrated to be effective.

The Alberta Piping Plover Recovery Team believes that all of the conditions necessary for recovery to be feasible are met. The plover population in Alberta appears to have sufficient habitat in which to breed, although it is possible that the quality of this habitat has deteriorated in recent decades due to increased predator populations, recreational use of shorelines, drought, and other threats (Prescott 2004). As a result, natural production is likely lower than is required to sustain the population. However, recent management efforts in Alberta have improved habitat 
quality in many areas, and have secured the long-term availability of high-quality habitat through the establishment of sanctuaries, the execution of cooperative stewardship agreements with landowners and lessees, and through education and extension activities. In addition, the protection of nests with predator exclosures has vastly improved nesting success to the point where productivity goals have been met or exceeded, and population recovery is theoretically probable (Alberta Piping Plover Recovery Team 2005, Prescott et al. 2010; see also Larson et al. 2003). These successes have occurred with relatively modest amounts of funding, at levels that should be sustainable in the future. Increased awareness and support for recovery efforts for the piping plover in Alberta also prompts optimism about the probability of population recovery in this province.

It is important to acknowledge that there are a number of factors affecting recovery that are beyond the control of the Alberta Piping Plover Recovery Team or this recovery plan. For example, the piping plover's migratory nature and international life cycle requirements mean that the policies and actions of numerous governments and industries will affect the success of recovery efforts in Alberta. The effects of drought on habitat availability and predator densities also cannot be controlled. For these reasons, it is expected that plovers will require long-term management in the province to ensure that the recovery goal is met and that the local population remains viable. Fortunately, emigration of plovers from Alberta is relatively low. Therefore, conservation efforts and funding directed at recovery of plovers in Alberta directly affects the provincial population.

\subsection{Guiding Principles}

The recovery and management of piping plovers in Alberta will be guided by principles that were established during the inaugural recovery plan (Alberta Piping Plover Recovery Team 2002):

- Recovery of the piping plover is both possible and desirable

- The loss of habitat and individuals is unacceptable

- A cooperative approach with landowners, industry and other agencies is essential. This includes shared stewardship, compatible land use and local commitment to management initiatives

- Management actions will employ tools resulting in the most immediate benefit to piping plovers, and will be based on the best information available. However, implementation will not be delayed because of a lack of specific supporting information

- Landowners and leaseholders will not be unduly affected by the costs associated with maintaining or enhancing piping plover habitat, or other recovery measures

- Activities will be restricted to a small number of effective and achievable actions

- Recovery actions will embrace an ecosystem (holistic) approach to management

- Predator management activities will be accomplished through passive means (deterrence)

- The recovery process will be guided by the concept of adaptive management, whereby recovery actions are evaluated and are revisited, as necessary, to ultimately improve the outcome. 


\section{$\underline{7.3 \text { Recovery Goal }}$}

The Alberta recovery goal is to achieve a well-distributed, long-term average population of 300 individual piping plovers within their historical breeding range in Alberta. This goal has remained unchanged since the inaugural recovery plan (Alberta Piping Plover Recovery Team 2002), and is consistent with the Recovery Strategy for the Piping Plover (Charadrius melodus circumcinctus) in Canada (Environment Canada 2006), and the directives of the Minister's Initial Conservation Action Statement. To be entirely consistent with national goals (Environment Canada 2006), we clarify here that the target population size should be maintained over three international census periods (11 years) before recovery is considered to be attained.

\subsection{Recovery Objectives}

The recovery goal will be achieved by meeting several objectives:

1) To minimize anthropogenic impacts on the quantity and quality of piping plover habitat

2) To employ all management techniques possible to achieve a median fledging rate of greater than 1.25 chicks/pair/year in the province

3) To increase public awareness of piping plovers and their management in Alberta, and

4) To monitor the progress of past and current management efforts in the province.

\subsection{Strategies for Recovery}

The goal and objectives of the Alberta Piping Plover Recovery Plan 2010-2020 will be achieved through the implementation of six distinct strategies, which will be pursued concurrently over the ten-year period. Whenever possible, these strategies and their associated actions will be integrated with those of other species at risk recovery efforts in the province, and with management efforts for piping plovers in other jurisdictions in Canada and the United States. The listed strategies, and associated actions, are virtually identical to those listed in previous recovery plans for this species (Alberta Piping Plover Recovery Team 2002, 2006). The success of those plans means that much of the groundwork for the current plan has been laid, and an increasing emphasis will be placed on maintaining existing partnerships, management agreements and other activities, as much as it will be to begin new initiatives.

\section{These strategies are:}

Habitat Management and Protection - All actions related to assessing and improving the quality and security of breeding habitat for piping plovers in Alberta. Particular emphasis will be placed on the management/protection of sites that meet the criteria of "critical habitat" in Alberta (see Section 4.0). Existing legislation, tools, policies and processes that are applicable to the protection of habitat in Alberta will be used whenever possible. Increasing emphasis will be placed on the maintenance of projects initiated during earlier recovery efforts.

Productivity Enhancement - All activities related to reducing depredation of piping plover eggs, chicks and adults. The prevention of nest loss will be the major activity under this strategy, 
because simple and measurably effective tools have been developed to counteract high rates of nest depredation in Alberta.

Information and Outreach - All actions related to providing information and extension to landowners/leaseholders, industrial interests, recovery partners, and the general public about the conservation and management of piping plovers in Alberta. The focus will be on preventing the degradation or loss of habitat, expanding awareness of conservation issues related to piping plovers, ensuring that stakeholders are informed of local recovery initiatives and results of these initiatives, and gaining (and maintaining) support and participation in management activities.

Population Monitoring and Research - All activities relating to the monitoring of population size and distribution, breeding success, and habitat threats and condition for piping plovers in Alberta. These efforts are required in order that management can be effectively applied where and when it is most needed.

Plan Management and Administration - All activities related to the operation of the Alberta Piping Plover Recovery Team, and implementation of the Alberta Piping Plover Recovery Plan. A key element of this strategy is to build linkages with other provincial, national and international initiatives that will benefit piping plover conservation in Alberta.

Resource Acquisition - All actions related to securing funding and other resources needed to support management actions detailed in this plan.

\subsection{ACTION PLAN}

The recovery actions outlined below form the basis of a 10-year plan aimed at achieving the recovery goal for Alberta. The listed actions are virtually unchanged from those listed in the first two provincial recovery plans (Alberta Piping Plover Recovery Team 2002, 2006), and are a subset of a more inclusive list of potential activities provided in the Recovery Strategy for the Piping Plover (Charadrius melodus circumcinctus) in Canada (Environment Canada 2006).

\section{$\underline{\text { 8.1 Habitat Management and Protection }}$}

1. Identify ownership (public or private) of all newly discovered plover sites on an annual basis. If land is crown owned, an application for a protective notation will be submitted to the Lands Division of Alberta Sustainable Resource Development or the Special Areas Board. If land is privately owned, the landowner will be contacted regarding plovers and their management.

2. Maintain the recovery team leader as the key contact in the industrial referral system for consultation regarding industrial activities that affect habitat of plover-inhabited lakes.

3. Continually seek opportunities for, and negotiate cooperative agreements with landowners/leaseholders to mitigate threats to plover habitat. 
4. Implement habitat-improvement actions specified in cooperative agreements, with the lead organization to be determined on a case-by-case basis.

5. Annually assess habitat quality, threats, and management opportunities on all plover-occupied lakes, with a focus on areas designated under the federal Species at Risk Act as being "critical habitat".

6. Annually assess habitat quality and threats on all areas where past management activities have been undertaken, to assess effectiveness of management activities. Maintain positive relationships with existing cooperators, and ensure that previously completed projects (e.g. signage, fencing, etc.) are maintained to maximize benefits for plovers and cooperators into the future.

\section{$\underline{8.2 \text { Productivity Enhancement }}$}

1. Annually implement the predator exclosure project on as many lakes as available personnel and funding will allow.

2. Employ and expand, where possible, the use of specific predator deterrence measures recommended by Schmelzeisen et al. (2004) to increase plover productivity and survivorship.

3. Produce and distribute an annual report on productivity enhancement activities to funders, stakeholders and other interested parties.

\section{$\underline{8.3 \text { Information and Outreach }}$}

1. Provide information on plover-related issues to technical and non-technical audiences through presentations, signage, and other media.

2. Maintain annual contact with all landowners, cottagers, industry, and other land users that have cooperated in piping plover management.

3. Produce and distribute an annual newsletter for cooperators, funding partners, and other individuals and agencies.

\section{$\underline{8.4 \text { Population Monitoring and Research }}$}

1. Conduct annual adult and brood surveys on a core of at least 25 lakes each year depending on water cycles and habitat availability. All lakes listed as "critical habitat" under the federal Species at Risk Act will be visited.

2. Coordinate and participate in the 2011 and 2016 International Piping Plover Censuses.

3. Identify, through remote digital imagery, specific predators of piping plover nests and young in order to improve management techniques used to enhance productivity. 
4. Continue with opportunistic banding, and compilation of observations of banded birds.

5. Cooperate with any provincial, national, and international initiatives that will provide information to better manage piping plovers in Alberta.

\subsection{Plan Management and Administration}

1. Convene the Alberta Piping Plover Recovery Team annually and circulate results of these meetings to interested persons.

2. Monitor and assess the progress of recovery plan actions, and develop new recovery strategies and actions when needed.

3. Liaise with the Prairie Piping Plover Recovery Team and other provincial, multi-provincial, or international conservation initiatives and municipal governments to ensure continuity and flow of information between agencies.

4. Enter accumulated plover data into the Fisheries and Wildlife Management Information System (FWMIS) and other centralized databases following each field season.

5. Prepare and distribute a comprehensive report at five-year intervals on all recovery plan activities.

\section{$\underline{8.6 \text { Resource Acquisition }}$}

1. Approach government, non-government, and industry partners to participate in or fund piping plover recovery initiatives.

2. Hire and train seasonal staff to participate in annual field programs, and provide training/orientation to staff of cooperating agencies (government and non-government) when opportunities arise.

\subsection{IMPLEMENTATION SCHEDULE AND COSTS}

Table 1 provides a timeline and estimated costs (including direct and "in-kind") for implementation of activities detailed in Section 8.0. The total cost over the 10-year implementation period is $\$ 2,020,000$. In general, costs are relatively static from year to year (range of $\$ 182,000$ in 2010-11 and 2012-13 to $\$ 219,000$ in 2016-17), because most activities will occur in all years during the implementation period. However, the budget includes modest cost increases over the life of the plan to account for annual inflation, a reduction in habitat improvement costs over time (item 8.1.3 and 8.1.4) with an accompanying increase in maintenance costs (8.1.6), and year-specific expenses of major report writing (8.5.5), 
Table 1. Schedule and costs (direct and "in-kind", in thousands) for implementation of piping plover recovery activities, 2010-2020. Alberta Sustainable Resource Development will be responsible for overseeing all activities, but individual actions may be led by agencies represented on the recovery team, or other partners.

\begin{tabular}{|c|c|c|c|c|c|c|c|c|c|c|c|c|}
\hline $\begin{array}{l}\text { Plan } \\
\text { Section }\end{array}$ & Action & 2010-11 & 2011-12 & 2012-13 & 2013-14 & 2014-15 & 2015-16 & 2016-17 & 2017-18 & 2018-19 & 2019-20 & Total \\
\hline 8.1 & Habitat Management \& Protection & & & & & & & & & & & \\
\hline 1. & Notations/landowner contact & 3 & 3 & 3 & 3 & 4 & 4 & 4 & 4 & 4 & 4 & 36 \\
\hline 2. & Liaison in industrial referral system & $*$ & $*$ & $*$ & * & $*$ & * & * & * & * & * & $*$ \\
\hline 3. & Cooperative agreements & 10 & 10 & 10 & 8 & 8 & 8 & 8 & 5 & 5 & 5 & 77 \\
\hline 4. & Implement habitat improvement & 25 & 25 & 25 & 20 & 20 & 20 & 20 & 15 & 15 & 15 & 200 \\
\hline 5. & Monitor critical habitat & 5 & 5 & 5 & 6 & 6 & 6 & 6 & 7 & 7 & 7 & 60 \\
\hline \multirow[t]{2}{*}{6.} & \multirow[t]{2}{*}{ Monitor/maintain managed habitat } & 5 & 5 & 5 & 10 & 10 & 10 & 10 & 15 & 15 & 15 & 100 \\
\hline & & 48 & 48 & 48 & 47 & 48 & 48 & 48 & 46 & 46 & 46 & 473 \\
\hline 8.2 & Productivity Enhancement & & & & & & & & & & & \\
\hline 1. & Predator exclosure project & 65 & 65 & 65 & 70 & 70 & 70 & 70 & 75 & 75 & 75 & 700 \\
\hline 2. & Predator deterrent measures & 2 & 2 & 2 & 2 & 2 & 3 & 3 & 3 & 3 & 3 & 25 \\
\hline \multirow[t]{2}{*}{3.} & \multirow[t]{2}{*}{ Annual report } & 3 & 3 & 3 & 3 & 3 & 4 & 4 & 4 & 4 & 4 & 35 \\
\hline & & 70 & 70 & 70 & 75 & 75 & 77 & 77 & 82 & 82 & 82 & 760 \\
\hline 8.3 & Information \& Outreach & & & & & & & & & & & \\
\hline 1. & Presentations & * & $*$ & * & * & $*$ & * & * & * & $*$ & $*$ & $*$ \\
\hline 2. & Contact with cooperators & 3 & 3 & 3 & 4 & 4 & 4 & 5 & 5 & 5 & 5 & 41 \\
\hline \multirow[t]{2}{*}{3.} & \multirow[t]{2}{*}{ Annual newsletter } & 2 & 2 & 2 & 2 & 2 & 3 & 3 & 3 & 3 & 3 & 25 \\
\hline & & 5 & 5 & 5 & 6 & 6 & 7 & 8 & 8 & 8 & 8 & 66 \\
\hline 8.4 & Population Monitoring \& Research & & & & & & & & & & & \\
\hline 1. & Population monitoring & 30 & 15 & 30 & 30 & 35 & 35 & 15 & 40 & 40 & 40 & 310 \\
\hline 2. & International Census & 0 & 30 & 0 & 0 & 0 & 0 & 35 & 0 & 0 & 0 & 65 \\
\hline 3. & Remote predator surveillance & * & * & * & * & * & 5 & * & $*$ & $*$ & $*$ & 5 \\
\hline 4. & Banding & * & * & * & * & * & * & * & * & * & * & * \\
\hline \multirow[t]{2}{*}{5.} & \multirow[t]{2}{*}{ Cooperate with other initiatives } & $*$ & $*$ & * & $*$ & * & * & * & * & * & * & * \\
\hline & & 30 & 45 & 30 & 30 & 35 & 40 & 50 & 40 & 40 & 40 & 380 \\
\hline 8.5 & Plan Management \& Administration & & & & & & & & & & & \\
\hline 1. & Annual recovery team meeting & 1 & 1 & 1 & 1 & 1 & 1 & 1 & 1 & 1 & 1 & 10 \\
\hline 2. & Evaluate recovery actions & $*$ & * & $*$ & $*$ & * & * & * & * & * & * & * \\
\hline 3. & Liaison with other plover initiatives & * & * & $*$ & * & * & * & * & * & * & * & * \\
\hline 4. & Database management & 7 & 7 & 7 & 8 & 8 & 8 & 9 & 9 & 9 & 9 & 81 \\
\hline \multirow[t]{3}{*}{5.} & Five-year report & 0 & 0 & 0 & 0 & 5 & 0 & 0 & 0 & 0 & 0 & 5 \\
\hline & \multirow[t]{2}{*}{ Overall coordination } & 15 & 15 & 15 & 17 & 17 & 17 & 18 & 20 & 20 & 20 & 174 \\
\hline & & 23 & 23 & 23 & 26 & 31 & 26 & 28 & 30 & 30 & 30 & 270 \\
\hline 8.6 & Resource Acquisition & & & & & & & & & & & \\
\hline \multirow{3}{*}{$\begin{array}{l}1 . \\
2 .\end{array}$} & \multirow{3}{*}{$\begin{array}{l}\text { Funding securement } \\
\text { Staff training }\end{array}$} & 6 & 6 & 6 & 7 & 7 & 7 & 8 & 8 & 8 & 8 & 71 \\
\hline & & $*$ & $*$ & $*$ & * & * & $*$ & $*$ & * & * & * & * \\
\hline & & 6 & 6 & 6 & 7 & 7 & 7 & 8 & 8 & 8 & 8 & 71 \\
\hline & TOTAL & 182 & 197 & 182 & 191 & 202 & 205 & 219 & 214 & 214 & 214 & 2020 \\
\hline
\end{tabular}

${ }^{*}$ Costs are included in daily operations of identified organizations, or in other actions 
participation in International Censuses (8.4.2), and replacement cost of equipment for predator monitoring (8.4.3). It is anticipated that a variety of agencies will participate in the funding and implementation of these activities.

\subsection{SOCIO-ECONOMIC CONSIDERATIONS}

It is a guiding principle of the Alberta Piping Plover Recovery Team that landowners and leaseholders should not be unduly affected by costs associated with implementation of the plan (see Section 7.2). However, potential economic costs affecting landholders and industrial developers may include occasional restrictions on land-use activities, or on timing of these activities. Restrictions on use or timing of shorelines for recreational activities could impact cottagers or tourists, but it is unlikely that complete restriction of beaches would be needed. A potential economic benefit for leaseholders and landowners is increased productivity of their lands (e.g., for grazing) following habitat management activities aimed at improving habitat for piping plovers. In addition, conservation and stewardship of lakeshore habitat for piping plovers will benefit a variety of other wildlife species and may increase biodiversity in these areas.

There is considerable public interest in piping plovers, making this an ideal species for increasing awareness and support for the conservation of other "at risk" wildlife and their habitats. Plovers are considered a priority species for birdwatchers (Goossen et al. 2002). Recreational viewing (birdwatching) has high social value and also has economic value in terms of its potential for ecotourism. However, economic benefits to local business and the provincial government are likely low, given plover lakes are generally great distances from major urban centres, and access is often difficult (Environment Canada 2009b).

\subsection{PLAN REVIEW AND AMENDMENT}

The Alberta Piping Plover Recovery Plan, 2010-2020 is designed to provide direction on conservation and recovery of the species for ten years from the date of Ministerial approval. Approval was attained following an internal review for content and format and a review by Alberta's Endangered Species Conservation Committee in spring 2010. During the ensuing ten years, mid 2010-mid 2020, the Department of Sustainable Resource Development and several other government and non-government organizations will be encouraged to implement the actions identified in the recovery plan. Annual meetings of the recovery team will be held to monitor implementation of the actions. A report on the results of these reviews will be submitted annually to the Director of Wildlife Management. Following this ten-year period the plan will be revisited and revised as needed or, if major changes are needed the team may be reconvened to rewrite the plan. Evaluations will be based on the comparison of specific performance measures to the stated recovery objectives.

This plan will represent the Ministerial-approved recovery plan for piping plovers in Alberta until a revised plan replaces it, regardless of time elapsed. For example should for any reason there be no revised plan approved by mid 2020, then this plan will continue to be the Alberta recovery plan for any period of months or years thereafter, until a revised plan is approved. 


\subsection{REFERENCES}

Alberta Fish and Wildlife Division. 1991. Management plan for the piping plover in Alberta (final draft). Alberta Fish and Wildlife Division, Edmonton, AB. 67 pp.

Alberta Sustainable Resource Development. 2009. Restricted activity periods and setback guidelines for the protection of sensitive wildlife species within grassland and parkland natural regions of Alberta. Alberta Fish and Wildlife Division, Prairies Area, Calgary, AB. $168 \mathrm{pp}$.

Alberta Piping Plover Recovery Team. 2002. Alberta Piping Plover Recovery Plan, 2002-2004. Alberta Sustainable Resource Development, Fish and Wildlife Division, Alberta Species at Risk Report Recovery Plan No. 2, Edmonton, AB. 21 pp.

Alberta Piping Plover Recovery Team. 2005. Implementation of the Alberta Piping Plover Recovery Plan, 2002-2004: Final program report. Alberta Sustainable Resource Development, Fish and Wildlife Division, Alberta Species at Risk Report No. 99, Edmonton, AB. 19 pp.

Alberta Piping Plover Recovery Team. 2006. Alberta Piping Plover Recovery Plan, 2005-2010. Alberta Sustainable Resource Development, Fish and Wildlife Division, Alberta Species at Risk Recovery Plan No. 10. Edmonton, AB. 27 pp.

Bjorge, R. R. 1997. The 1996 piping plover census in Alberta. Pp. 158-163 in 1996 International piping plover census (J. H. Plissner and S.M. Haig, eds.). Report to U.S. Geological Survey, Biological Resources Division, Forest and Rangeland Ecosystem Science Center, Corvallis, Oregon. 231 pp.

Bjorge, R. R., and A. J. Murphy. 2004. The 1996 piping plover census in Alberta. Pp. 117-139 in The 1996 International Piping Plover Census in Canada (J.P. Goossen and D. L. Amirault, eds.). Canadian Wildlife Service, Technical Report Series No. 416, Edmonton, AB and Sackville, NB. 164 pp.

Bottitta, G. E., A. M. Cole, and B. Lapin. 1997. Piping plovers produce two broods. Wilson Bull. 109:337-339.

Burger, J. 1994. The effect of human disturbance on foraging behavior and habitat use in piping plover (Charadrius melodus). Estuaries and Coasts 17:695-701.

Cairns, W. E. 1982. Biology and behavior of breeding piping plovers. Wilson Bull. 94:531545.

Canadian Permanent Committee on Geographic Names. 1988. Gazetteer of Canada: Alberta, 3rd edition. Department of Energy, Mines and Resources, Ottawa, ON. 64 pp. 
COSEWIC. 2009. Canadian species at risk. Committee on the Status of Endangered Wildlife in Canada, Ottawa, ON (available at http://www.cosewic.gc.ca/eng/sct0/rpt/dsp_booklet_e.htm).

Elliott-Smith, E., and S. M. Haig. 2004. Piping plover (Charadrius melodus). The birds of North America online (A. Poole, ed.). Cornell Lab of Ornithology, Ithaca, NY. http://bna.birds.cornell.edu/bna/species/002

Elliott-Smith, E., Haig, S.M., and B.M. Powers. 2009. Data from the 2006 International Piping Plover Census: U.S. Geological Survey Data Series 426, Corvallis, OR. 332 pp.

Engley, L., and D. R. C. Prescott. 2004. Alberta piping plover predator exclosure and population monitoring program. Pp. 12-14 in Northern Great Plains Piping Plover Science Workshop, November 2003 (S. M. Westworth, D. Martens, C. L. Gratto-Trevor, J. P. Goossen and S. Davis, eds.). Regina, SK. 60 pp.

Engley, L., D. Prescott, and R. Schmelzeisen. 2004. Alberta piping plover predator exclosure and population monitoring program. 2004 field season report. Alberta Conservation Association, Edmonton, AB. 29 pp.

Engley, L., and R. Schmelzeisen. 2002. Alberta piping plover predator exclosure and population monitoring program. 2002 field season report. Alberta Conservation Association, Edmonton, AB. 22 pp.

Environment Canada. 2006. Recovery strategy for the piping plover (Charadrius melodus circumcinctus) in Canada. Species at Risk Act Recovery Strategy Series. Environment Canada, Ottawa. $29 \mathrm{pp}+$ appendices.

Environment Canada. 2007. Addendum to the final recovery strategy for the piping plover (Charadrius melodus circumcinctus) in Canada: Identification of critical habitat. Environment Canada, Ottawa. 12 pp.

Environment Canada. 2009a. (Draft) Species at Risk Act policies. Species at Risk Act Policies and Guidelines Series, Environement Canada, Ottawa, ON. 38 pp.

Environment Canada. 2009b. (Proposed) Action plan for the piping plover (Charadrius melodus circumcinctus) in Alberta. Environment Canada, Ottawa. 10 pp. + appendices.

Espie, R. H. M., R. M. Brigham, and P. C. James. 1992. Breeding ecology of the piping plover at Lake Diefenbaker, Saskatchewan. Unpubl. rept. for Canadian Wildlife Service, Edmonton, AB. 31 pp.

Espie, R. H. M., R. M. Brigham, and P. C. James. 1998. The effects of flooding on piping plover Charadrius melodus reproductive success at Lake Diefenbaker, Saskatchewan, Canada. Biol. Conserv. 86:215-222. 
Flemming, S. P., R. D. Chiasson, P. C. Smith, P. J. Austin-Smith, and R. P. Bancroft. 1988. Piping plover in Nova Scotia related to its reproductive and behavioural responses to human disturbance. J. Field Ornithol. 59:321-330.

Goossen, J. P. 1994. Prairie piping plover conservation: 1992 and 1993. Unpublished draft report, Canadian Wildlife Service, Edmonton, AB. 34 pp.

Goossen, J. P., D. L. Amirault, S. Richard, R. Bjorge, J. Brazil, S. Brechtel, R. Chiasson, G. N. Corbett, F. R. Curley, M. Elderkin, S. P. Flemming, W. Harris, L. Heyens, D. Hjertaas, M. Huot, R. Jones, W. Koonz, P. Laporte, R. I. G. Morrison, C. Stewart, L. Swanson and E. Wiltse. 2002. National recovery plan for piping plover (Charadrius melodus). National Recovery Plan No. 22. Recovery of Nationally Endangered Wildlife. Ottawa, ON. 47 pp.

Goossen, J. P., S. M. Westworth, B. Yee, D. Thorson, and I. Michaud. 2000. Atlas of piping plovers in the Canadian prairie provinces and Ontario. Multimedia CD-ROM atlas produced by Environment Canada, Edmonton and Regina.

Goossen, J. P., D. L. Amirault-Langlais, E. Elliott-Smith and S. M. Haig. In prep. Piping plover conservation in Canada (2001-2006) in J.P. Goossen and D.L. Amirault-Langlais (eds.). The 2006 International Piping Plover Census in Canada. Technical Report Series No. 490. Canadian Wildlife Service (Environment Canada), Edmonton, AB and Sackville, NB. 158 pp.

Haig, S. M. 1985. Updated status report on the piping plover Charadrius melodus in Canada. Committee on the Status of Endangered Wildlife in Canada, Ottawa, ON. 23 pp.

Haig, S. M., W. Harrison, R. Lock, L. Pfannmuller, E. Pike, M. Ryan, and J. Sidle. 1988. Recovery plan for piping plovers (Charadrius melodus) of the Great Lakes and northern Great Plains. U. S. Fish and Wildlife Service, Twin Cities, MN. 160 pp.

Haig, S. M., and L. W. Oring. 1988a. Mate, site, and territory fidelity in piping plovers. Auk 105:268-277.

Haig, S. M., and L. W. Oring. 1988b. Distribution and dispersal in the piping plover. Auk 105:630-638.

Haig, S. M., and J. Plissner. 1993. Distribution and abundance of piping plovers: results and implications of the 1991 International census. Condor 95:145-156.

Haig, S. M., C. L. Ferland, F. J. Cuthbert, J. Dingledine, J. P. Goossen, A. Hecht, and N. McPhillips. 2005. A complete species census and evidence for regional declines in piping plovers. J. Wildl. Manage. 69:160-173.

Harris, W. C., D. C. Duncan, R. J. Franken, D. T. McKinnon, and H. A. Dundas. 2005. Reproductive success of piping plovers at Big Quill Lake, Saskatchewan. Wilson Bull. 117:165-171. 
Heckbert, M. D. 1994. Piping plover (Charadrius melodus) ecology and conservation in Alberta (1994): Reflex Lake and Killarney Lake field report. Unpubl. rept., Alberta Fish and Wildlife Services, Vermilion, AB. 152 pp.

Heckbert, M. D., and K. D. Cantelon. 1996. Piping plover (Charadrius melodus) ecology and conservation in Alberta (1995): east-central Alberta field report. Unpubl. rept. for Natural Resources Service and Alberta NAWMP Centre, Edmonton, AB. 163 pp.

Hofman, D. E. 1992. 1992 piping plover survey, Little Fish Lake, Alberta. Unpubl. rept., Alberta Fish and Wildlife Division, Red Deer, AB. 16 pp.

Hofman, D. E. 1994. The 1991 piping plover census in Alberta. Pp. 43-47 in The 1991 International Piping Plover Census in Canada (S. P. Flemming, ed.). Canadian Wildlife Service Occasional Paper No. 82. 59 pp.

Ivan, J. S., and R. K. Murphy. 2005. What preys on piping plover eggs and chicks? Wildl. Soc. Bull. 33:113-119.

Jung, T. S., J. P. Goossen, B. Aitken, and I. A. Bisson. 1998. Conservation biology of piping plovers at Lake Diefenbaker, Saskatchewan: 1997 progress report. Unpubl. rept., Canadian Wildlife Service, Edmonton, AB. 49 pp. + appendices.

Larson, M. A., M. R. Ryan, and B. G. Root. 2000. Piping plover survival in the Great Plains: an updated analysis. Journal of Field Ornithology 71:721-729.

Larson, M. A., M. R. Ryan, and R. K. Murphy. 2003. Assessing recovery feasibility for piping plovers using optimization and simulation. Wildlife Society Bulletin 31:1105-1116.

Melvin, S. M., L. H. MacIvor, and C. R. Griffin. 1992. Predator exclosures: a technique to reduce predation at piping plover nests. Wildl. Soc. Bull. 20:143-148.

Michaud, I., and D. Prescott. 1999. Use of predator exclosures to protect piping plover nests in Alberta and Saskatchewan: 1999 field season report. Alberta Conservation Association, Edmonton, AB. 9 pp. + appendices.

Murphy, R. K., I. M. G. Michaud, D. R. C. Prescott, J. S. Ivan, B. J. Anderson, and M. L. French-Pombier. 2003. Predation on adult piping plovers at predator exclosure cages. Waterbirds 26:150-155.

Murphy, R. K., B. G. Root, P. M. Mayer, J. P. Goossen, and K. A. Smith. 1999. A draft protocol for assessing piping plover reproductive success on Great Plains alkali lakes. Pp. 90-107 in K. F. Higgins, M.R. Brashier and C. D. Kruse (eds.), Proceedings, piping plovers and least terns of the Great Plains and nearby. South Dakota State University, Brooking. $132 \mathrm{pp}$. 
Murphy, R. K., M. L. Sondreal, D. A. Guenther, and M. P. Nenneman. 1995. Reproductive success of piping plovers on alkali lakes in northwestern North Dakota. Pp. 13-21 in Conservation of piping plovers in northwestern North Dakota. 1995 annual report. 19 pp. + appendices.

Pinel, H. W., W. W. Smith, and C. R. Wershler. 1991. Alberta birds, 1971-1980. Provincial Museum of Alberta, Natural History Occasional Paper No. 13, Edmonton, AB. 243 pp.

Plissner, J. H., and S. M. Haig. 2000. Viability of piping plover Charadrius melodus metapopulations. Biol. Conserv. 92:163-173.

Prescott, D. R. C. 1997. Status of the piping plover (Charadrius melodus) in Alberta. Alberta Environmental Protection, Wildlife Management Division, Wildlife Status Report No. 1, Edmonton, AB. 19 pp.

Prescott, D. R. C. 2001a. Aerial reconnaissance surveys for piping plover habitat in east-central Alberta, May 2001. Alberta Sustainable Resource Development, Fish and Wildlife Division, Alberta Species at Risk Report No. 26, Edmonton, AB. 10 pp.

Prescott, D. R. C. 2001b. The 2001 International Piping Plover Census in Alberta. Alberta Sustainable Resource Development, Fish and Wildlife Division, Alberta Species at Risk Report No. 27, Edmonton, AB. 15 pp.

Prescott, D. R. C. 2004. The role of habitat: is it a limiting factor on the breeding grounds? Pp. 6-8 in Northern Great Plains Piping Plover Science Workshop, November 2003 (S.M. Westworth, D. Martens, C.L. Gratto-Trevor, J. P. Goossen and S. Davis, eds.). Canadian Wildlife Service, Regina, SK. 60 pp.

Prescott, D. 2009. The 2006 International Piping Plover Breeding Census in Alberta. Pp 271276 in Data from the 2006 International Piping Plover Census (E. Elliott-Smith, S. M. Haig, and B. M. Powers, eds.). U.S. Geological Survey Data Series 426, 332 pp. Available at: http://pubs.usgs.gov/ds/426/pdf/ds426.pdf.

Prescott, D. R. C., L. C. Engley, and D. Sturgess. 2010. Implementation of the Alberta Piping Plover Recovery Plan, 2005-2010: Final program report. Alberta Sustainable Resource Development, Fish and Wildlife Division, Alberta Species at Risk Report, Edmonton, AB. In press.

Prindiville Gaines, E., and M. R. Ryan. 1988. Piping plover habitat use and reproductive success in North Dakota. J. Wildl. Manage. 52:266-273.

Rezansoff, A., R. Schmelzeisen, L. Engley, and D. Prescott. 2006. Alberta piping plover predator exclosure and population monitoring program. Alberta Conservation Association, Edmonton, AB. 41 pp. 
Rezansoff, A., L. Engley, and D. Prescott. 2008. Alberta piping plover predator exclosure and population monitoring program. Alberta Conservation Association, Edmonton, AB. 47 pp.

Rezansoff, A., L. Engley, and D. Prescott. 2009. Alberta piping plover predator exclosure and population monitoring program. Alberta Conservation Association, Sherwood Park, AB. 32 pp.

Richardson, I. M. 1999. Predator exclosures: a management technique to increase piping plover (Charadrius melodus) reproductive success in the Canadian prairies. M.Sc. thesis, University of Alberta, Edmonton, AB. 65 pp.

Root, B. G., M. R. Ryan, and P. M. Mayer. 1992. Piping plover survival in the Great Plains. J. Field Ornithol. 63:10-15.

Ryan, M. R., B. G. Root, and P. M. Mayer. 1993. Status of piping plovers in the Great Plains of North America: a demographic simulation model. Conserv. Biol. 7:581-585.

Schmelzeisen, R., and L. Engley. 2003. Alberta piping plover predator exclosure and population monitoring program. 2003 field season report. Unpubl. rept., Alberta Conservation Association, Edmonton, AB. 26 pp.

Schmelzeisen, R., D. R. C. Prescott, and L. Engley. 2004. Methods for controlling depredation on piping plovers in Alberta: a literature review and synthesis. Alberta Sustainable Resource Development, Fish and Wildlife Division, Alberta Species at Risk Report No. 84, Edmonton, AB. 24 pp.

Schmelzeisen, R., L. Engley, A. Rezansoff,and D. Prescott. 2005. Alberta piping plover predator exclosure and population monitoring program. Alberta Conservation Association, Edmonton, AB. 35 pp.

U. S. Fish and Wildlife Service. 2009. Piping plover (Charadrius melodus) 5-year review: Summary and evaluation. U.S. Fish and Wildlife Service. U. S. Fish and Wildlife Service, Hadley, MA and East Lansing, MI. 206 pp.

van Huystee, S., R. Schmelzeisen, L. Engley, and D. Prescott. 2007. Alberta piping plover predator exclosure and population monitoring program. Alberta Conservation Association, Edmonton, AB. 44pp.

Wershler, C. R. 1992. An analysis of piping plover management concerns in Alberta. Unpubl. rept. for Alberta NAWMP Centre, Edmonton, AB. 56 pp.

Wershler, C., and C. Wallis. 1987. Status of the piping plover in Alberta, 1986. Unpubl. rept. for World Wildlife Fund Canada and Canadian Wildlife Service, Calgary, AB. 54 pp.

Wiltermuth, M. T., M. J. Anteau, M. H. Sherfy, and T. L. Shaffer. 2009. Nest movement by piping plovers in response to changing habitat conditions. Condor 111: 550-555 
Westworth, S. M., D. Martens, C. L. Gratto-Trevor, J. P. Goossen, and S. Davis. 2004. Northern Great Plains piping plover science workshop, November 2003, Regina, SK. 60 pp.

Whyte, A. J. 1985. Breeding biology of the piping plover (Charadrius melodus) in central Saskatchewan. M.Sc. thesis, University of Saskatchewan, Saskatoon, SK. 53 pp. 


\subsection{APPENDICES}

Appendix 1. Waterbodies known to have supported piping plovers in Alberta through 2009 (see Appendix 2 for map). Sources: Alberta Piping Plover Recovery Team (2006), Prescott (2009), Prescott et al. (2010).

\begin{tabular}{|c|c|c|c|c|c|c|c|}
\hline $\begin{array}{c}\text { Map } \\
\#\end{array}$ & Waterbody $^{1}$ & \begin{tabular}{|c|} 
\# Years \\
Surveyed \\
\end{tabular} & $\begin{array}{l}\text { \#Years } \\
\text { Present }\end{array}$ & $\begin{array}{c}\text { Population } \\
\text { Size }\end{array}$ & $\begin{array}{c}\text { Breeding } \\
\text { Confirmed }\end{array}$ & $\begin{array}{c}\text { Latitude } \\
\left({ }^{\circ} \mathrm{N}\right)\end{array}$ & \begin{tabular}{|c}
$\begin{array}{c}\text { Longitude } \\
\left({ }^{\circ} \mathrm{W}\right)\end{array}$ \\
\end{tabular} \\
\hline 1 & Akasu & 14 & 11 & $2-16$ & $\mathrm{Y}$ & 53.50 & 111.82 \\
\hline 2 & Albert & 8 & 2 & $2-6$ & $\mathrm{Y}$ & 53.17 & 110.45 \\
\hline 3 & Baxter & 17 & 15 & $2-15$ & $\mathrm{Y}$ & 52.94 & 110.73 \\
\hline 4 & Beaverhill & 20 & 18 & $1-13$ & $\mathrm{Y}$ & 53.45 & 112.53 \\
\hline 5 & Birch & 17 & 16 & $2-23$ & $\mathrm{Y}$ & 53.32 & 111.59 \\
\hline 6 & Bittern & 6 & 2 & 2 & $\mathrm{Y}$ & 53.05 & 113.08 \\
\hline 7 & Blood Indian Reservoir & 1 & 1 & 1 & $\mathrm{~N}$ & 51.25 & 111.22 \\
\hline 8 & Border & 6 & 6 & $1-2$ & $\mathrm{Y}$ & 52.62 & 110.72 \\
\hline 9 & Bow River/Carseland Prov. Park & 1 & 1 & 7 & $\mathrm{~N}$ & 50.83 & 113.43 \\
\hline 10 & Buffalo & 15 & 9 & $1-20$ & $\mathrm{Y}$ & 52.45 & 112.90 \\
\hline 11 & Chain "\#1" (Pearl) & 11 & 5 & $1-4$ & $\mathrm{Y}$ & 51.77 & 112.10 \\
\hline 12 & Chain “\#3" (Clear) & 8 & 4 & $1-2$ & $\mathrm{Y}$ & 51.79 & 112.13 \\
\hline 13 & Chain "\#4" & 24 & 24 & $1-24$ & $\mathrm{Y}$ & 51.80 & 112.15 \\
\hline 14 & Chain "\#6" & 5 & 1 & 2 & $\mathrm{Y}$ & 51.84 & 112.18 \\
\hline 15 & Chappice & 24 & 15 & $1-17$ & $\mathrm{Y}$ & 50.15 & 110.35 \\
\hline 16 & Chestermere & 3 & 1 & 1 & $\mathrm{~N}$ & 51.03 & 113.82 \\
\hline 17 & Cipher & 20 & 19 & $1-4$ & $\mathrm{Y}$ & 52.68 & 110.10 \\
\hline 18 & "Clark" & 6 & 6 & $3-15$ & $\mathrm{Y}$ & 52.27 & 110.75 \\
\hline 19 & Cochrane & 3 & 1 & 1 & $\mathrm{~N}$ & 51.25 & 114.48 \\
\hline 20 & Dalemead & 2 & 1 & 2 & $\mathrm{~N}$ & 50.92 & 113.62 \\
\hline 21 & Dawson & 2 & 1 & 1 & $\mathrm{~N}$ & 51.13 & 113.40 \\
\hline 22 & Dillberry & 5 & 1 & 3 & $\mathrm{~N}$ & 52.58 & 110.00 \\
\hline 23 & Dowling & 25 & 25 & $2-58$ & $\mathrm{Y}$ & 51.73 & 112.01 \\
\hline 24 & Eagle & 3 & 1 & 1 & $\mathrm{~N}$ & 51.00 & 113.32 \\
\hline 25 & "Foster" & 15 & 11 & $2-6$ & $\mathrm{Y}$ & 52.23 & 110.55 \\
\hline 26 & Frank & 4 & 2 & 3 & $\mathrm{Y}$ & 50.57 & 113.72 \\
\hline 27 & Frog & 9 & 9 & $3-15$ & $\mathrm{Y}$ & 53.92 & 110.33 \\
\hline 28 & Gillespie & 6 & 1 & 2 & $\mathrm{~N}$ & 52.42 & 110.18 \\
\hline 29 & Gooseberry & 15 & 11 & $1-9$ & $\mathrm{Y}$ & 52.12 & 110.73 \\
\hline 30 & Goosequill & 7 & 2 & 2 & $\mathrm{Y}$ & 52.05 & 113.15 \\
\hline 31 & "Greenlee" & 8 & 6 & $1-4$ & $\mathrm{Y}$ & 52.22 & 110.48 \\
\hline 32 & Gull & 5 & 4 & $1-6$ & $\mathrm{~N}$ & 52.57 & 114.00 \\
\hline 33 & Handhills & 25 & 25 & $2-82$ & $\mathrm{Y}$ & 51.49 & 112.12 \\
\hline 34 & Hansman & 5 & 3 & $1-6$ & $\mathrm{Y}$ & 52.39 & 110.39 \\
\hline 35 & Hattie & 2 & 1 & 1 & $\mathrm{~N}$ & 52.98 & 111.57 \\
\hline 36 & Horseshoe & 13 & 10 & $2-16$ & $\mathrm{Y}$ & 52.36 & 110.74 \\
\hline 37 & "Janet" & 3 & 1 & 1 & $\mathrm{~N}$ & 51.02 & 113.87 \\
\hline 38 & "Junction" & 8 & 5 & $2-14$ & $\mathrm{Y}$ & 53.45 & 111.75 \\
\hline 39 & Keho & 9 & 6 & $1-4$ & $\mathrm{Y}$ & 49.95 & 112.98 \\
\hline 40 & Killarney & 21 & 19 & $1-48$ & $\mathrm{Y}$ & 52.58 & 110.10 \\
\hline 41 & Leane & 11 & 5 & $1-2$ & $\mathrm{Y}$ & 52.56 & 110.07 \\
\hline 42 & Lesser Slave & 3 & 1 & 1 & $\mathrm{~N}$ & 55.45 & 115.45 \\
\hline 43 & Little Fish & 27 & 21 & $1-48$ & $\mathrm{Y}$ & 51.37 & 112.22 \\
\hline 44 & Long & 2 & 1 & 1 & $\mathrm{~N}$ & 51.22 & 113.42 \\
\hline
\end{tabular}




\begin{tabular}{|c|c|c|c|c|c|c|c|}
\hline $\begin{array}{c}\text { Map } \\
\#\end{array}$ & Waterbody $^{1}$ & \begin{tabular}{|c|} 
\# Years \\
Surveyed
\end{tabular} & $\begin{array}{l}\text { \# Years } \\
\text { Present }\end{array}$ & $\begin{array}{c}\text { Population } \\
\text { Size }\end{array}$ & $\begin{array}{l}\text { Breeding } \\
\text { Confirmed }\end{array}$ & $\begin{array}{l}\text { Latitude } \\
\left({ }^{\circ} \mathrm{N}\right)\end{array}$ & $\begin{array}{c}\text { Longitude } \\
\left({ }^{\circ} \mathrm{W}\right)\end{array}$ \\
\hline 45 & Lowden & 7 & 1 & unknown & $\mathrm{N}$ & 52.15 & 112.70 \\
\hline 46 & McDonald & 6 & 2 & $2-3$ & $\mathrm{~N}$ & 51.20 & 113.94 \\
\hline 47 & McGregor & 6 & 2 & $1-2$ & $\mathrm{Y}$ & 50.42 & 112.87 \\
\hline 48 & "McLaren" & 9 & 9 & $1-10$ & $\mathrm{Y}$ & 52.29 & 110.68 \\
\hline 49 & "Metiskow" & 18 & 13 & $1-8$ & $\mathrm{Y}$ & 52.40 & 110.63 \\
\hline 50 & Miquelon "\#1" & 4 & 1 & 1 & $\mathrm{~N}$ & 53.21 & 112.83 \\
\hline 51 & Miquelon "\#2" & 8 & 3 & $3-7$ & $\mathrm{Y}$ & 53.28 & 112.84 \\
\hline 52 & Miquelon “\#3" & 8 & 4 & $1-4$ & $\mathrm{Y}$ & 53.26 & 112.92 \\
\hline 53 & Mott & 5 & 3 & 2 & $\mathrm{Y}$ & 52.82 & 110.92 \\
\hline 54 & Muriel & 15 & 15 & $2-46$ & $\mathrm{Y}$ & 54.13 & 110.70 \\
\hline 55 & Namaka & 9 & 3 & $2-3$ & $\mathrm{Y}$ & 50.93 & 113.22 \\
\hline 56 & "Neutral Hills A" & 6 & 2 & $2-12$ & $\mathrm{Y}$ & 52.06 & 110.93 \\
\hline 57 & "Neutral Hills B1" & 5 & 2 & $2-4$ & $\mathrm{Y}$ & 52.09 & 110.94 \\
\hline 58 & "Neutral Hills B2" & 6 & 1 & 1 & $\mathrm{~N}$ & 52.10 & 110.97 \\
\hline 59 & "Neutral Hills C1" & 5 & 3 & $5-6$ & $\mathrm{Y}$ & 52.13 & 110.93 \\
\hline 60 & "Neutral Hills C2" & 3 & 1 & 3 & $\mathrm{~N}$ & 52.13 & 110.97 \\
\hline 61 & Newell & 5 & 3 & $1-3$ & $\mathrm{~N}$ & 50.43 & 111.92 \\
\hline 62 & Oliver & 4 & 1 & 2 & $\mathrm{~N}$ & 53.28 & 113.02 \\
\hline 63 & Pakowki & 1 & 1 & 1 & $\mathrm{~N}$ & 49.33 & 110.95 \\
\hline 64 & "Piper" & 17 & 15 & $2-15$ & $\mathrm{Y}$ & 52.33 & 110.63 \\
\hline 65 & Plain & 5 & 2 & $1-13$ & $\mathrm{Y}$ & 53.61 & 111.70 \\
\hline 66 & Plover & 6 & 1 & 6 & $\mathrm{~N}$ & 51.48 & 111.38 \\
\hline 67 & Red Deer & 12 & 11 & $2-16$ & $\mathrm{Y}$ & 52.70 & 113.05 \\
\hline 68 & Reesor & 3 & 1 & 1 & $\mathrm{~N}$ & 49.67 & 110.10 \\
\hline 69 & "Rider" & 20 & 13 & $1-17$ & $\mathrm{Y}$ & 52.52 & 112.77 \\
\hline 70 & Rockeling Bay & 19 & 9 & $2-30$ & $\mathrm{Y}$ & 52.57 & 112.82 \\
\hline 71 & "Rutherford"2 & 5 & 1 & 1 & $\mathrm{~N}$ & 50.13 & 110.25 \\
\hline 72 & Sam & 8 & 4 & $1-6$ & $\mathrm{Y}$ & 50.15 & 110.25 \\
\hline 73 & Sounding & 7 & 5 & $1-18$ & $\mathrm{Y}$ & 52.13 & 110.48 \\
\hline 74 & South Cooking & 1 & 1 & 2 & $\mathrm{~N}$ & 53.42 & 113.07 \\
\hline 75 & Spiers & 10 & 7 & $1-12$ & $\mathrm{Y}$ & 51.92 & 112.23 \\
\hline 76 & St. Mary Reservoir & 4 & 2 & $2-3$ & $\mathrm{~N}$ & 49.33 & 113.18 \\
\hline 77 & Stirling & 1 & 1 & 1 & $\mathrm{~N}$ & 49.53 & 112.58 \\
\hline 78 & Sunken & 19 & 18 & $2-10$ & $\mathrm{Y}$ & 52.38 & 110.65 \\
\hline 79 & Unnamed (E of Bruce Lake) & 1 & 1 & 1 & $\mathrm{~N}$ & 51.22 & 113.43 \\
\hline 80 & Unnamed (near Keoma) & 1 & 1 & 1 & $\mathrm{~N}$ & 51.23 & 113.58 \\
\hline 81 & Unnamed (near Water Valley) & 1 & 1 & 1 & $\mathrm{~N}$ & 51.50 & 114.60 \\
\hline 82 & Unnamed (E of Sheperd) & 1 & 1 & 1 & $\mathrm{~N}$ & 50.96 & 113.85 \\
\hline 83 & West & 4 & 3 & $2-6$ & $\mathrm{Y}$ & 52.23 & 110.73 \\
\hline 84 & "West" Reflex & 26 & 26 & $12-69$ & $\mathrm{Y}$ & 52.67 & 110.00 \\
\hline 85 & Whitewater & 2 & 1 & 1 & $\mathrm{~N}$ & 52.87 & 111.78 \\
\hline 86 & Whitford & 2 & 1 & 1 & $\mathrm{~N}$ & 53.87 & 112.25 \\
\hline
\end{tabular}

${ }^{1}$ Names of waterbodies not listed by the Canadian Permanent Committee on Geographic Names (1988) are considered to be unofficial names and are listed in quotations.

${ }^{2}$ Formerly referred to as "Unnamed (SE of Sam Lake)" 
Appendix 2. Map of waterbodies where piping plovers have been reported in Alberta. See Appendix 1 for details.

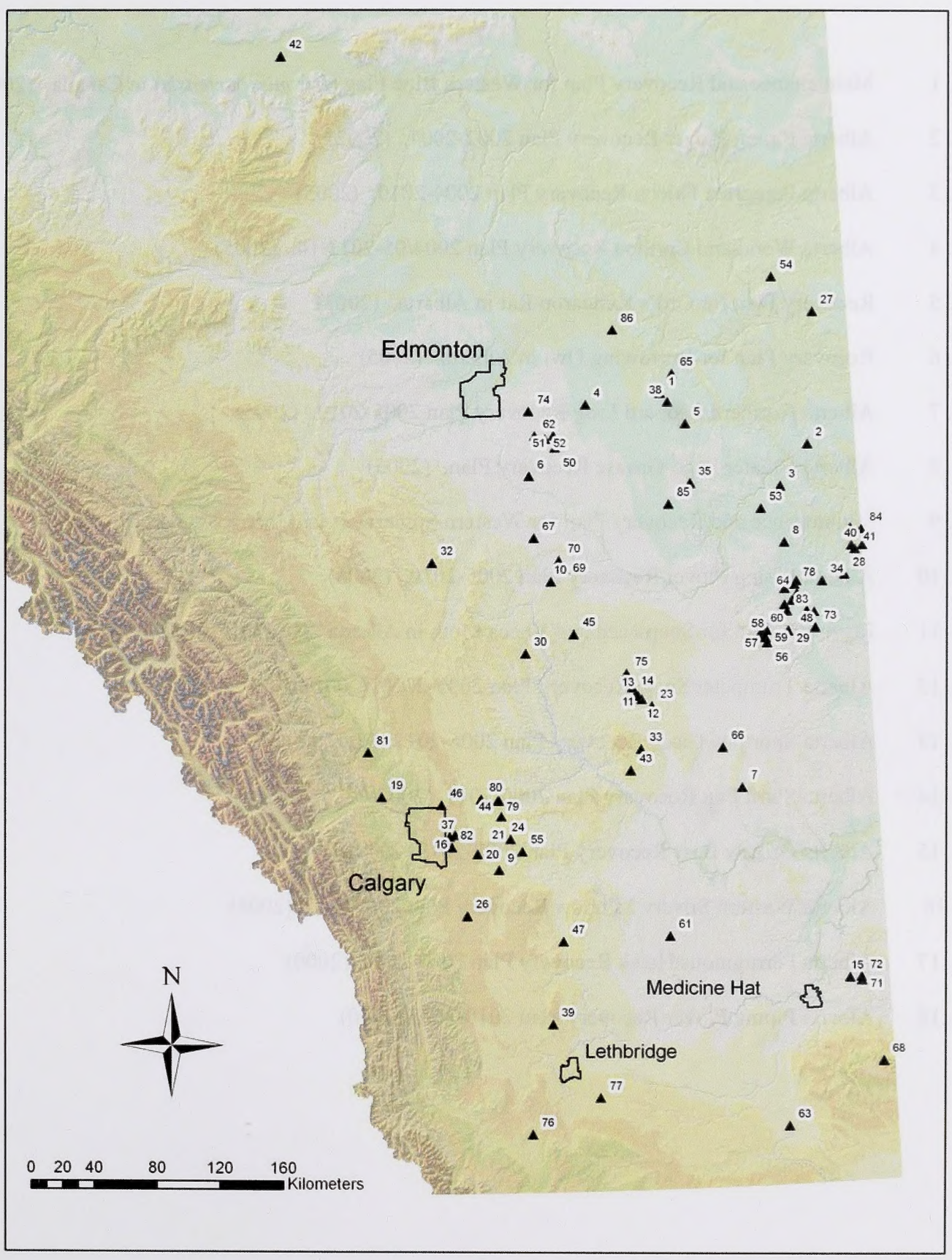




\section{List of Titles in the Alberta Species at Risk Recovery Plan Series}

(as of January 2010)

No. 1 Maintenance and Recovery Plan for Western Blue Flag (Iris missouriensis) in Canada. (2002)

No. 2 Alberta Piping Plover Recovery Plan 2002-2004. (2002)

No. 3 Alberta Peregrine Falcon Recovery Plan 2004-2010. (2005)

No. 4 Alberta Woodland Caribou Recovery Plan 2004/05-2013/14. (2005)

No. 5 Recovery Plan for Ord's Kangaroo Rat in Alberta. (2005)

No. 6 Recovery Plan for Burrowing Owl in Alberta. (2005)

No. 7 Alberta Northern Leopard Frog Recovery Plan 2005-2010. (2005)

No. 8 Alberta Greater Sage-Grouse Recovery Plan. (2005)

No. 9 Maintenance and Recovery Plan for Western Spiderwort in Alberta 2005-2010. (2005)

No. 10 Alberta Piping Plover Recovery Plan 2005-2010. (2006)

No. 11 Recovery Plan for Soapweed and Yucca Moth in Alberta 2006-2010. (2006)

No. 12 Alberta Trumpeter Swan Recovery Plan 2005-2010. (2006)

No. 13 Alberta Shortjaw Cisco Recovery Plan 2006-2011. (2007)

No. 14 Alberta Swift Fox Recovery Plan 2006-2011. (2007)

No. 15 Alberta Grizzly Bear Recovery Plan 2008-2013 (2008)

No 16 Alberta Western Silvery Minnow Recovery Plan 2008-2013 (2008)

No. 17 Alberta Ferruginous Hawk Recovery Plan 2009-2014. (2009)

No. 18 Alberta Piping Plover Recovery Plan 2010-2020 (2010) 



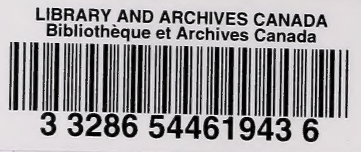

